Illinois State University

ISU ReD: Research and eData

Theses and Dissertations

5-7-2017

\title{
Altered Na,k-Atpase Isoform Expression In Artemia Franciscana In Response To Hypersaline Environments
}

Jessica Drenth

Illinois State University, jdrenth@ilstu.edu

Follow this and additional works at: https://ir.library.illinoisstate.edu/etd

Part of the Biochemistry Commons, Biology Commons, and the Molecular Biology Commons

\section{Recommended Citation}

Drenth, Jessica, "Altered Na,k-Atpase Isoform Expression In Artemia Franciscana In Response To Hypersaline Environments" (2017). Theses and Dissertations. 751.

https://ir.library.illinoisstate.edu/etd/751

This Thesis is brought to you for free and open access by ISU ReD: Research and eData. It has been accepted for inclusion in Theses and Dissertations by an authorized administrator of ISU ReD: Research and eData. For more information, please contact ISUReD@ilstu.edu. 


\title{
ALTERED NA,K-ATPASE ISOFORM EXPRESSION IN ARTEMIA FRANCISCANA IN RESPONSE TO HYPERSALINE ENVIRONMENTS
}

\author{
Jessica L. Drenth
}

38 Pages

The Na,K-ATPase (NKA) is an essential membrane pump that helps to establish cell ion gradients, and regulate intracellular salt in many organisms. One such species, Artemia

franciscana (brine shrimp), extreme halophiles which live in hypersaline environments, express 2 distinct $\alpha$-catalytic subunits of the NKA. One of these subunits, $\alpha 2-(\mathrm{KK})$, has two key lysine substitutions located within the cation binding sites. Prior work has demonstrated this specific subunit may be directly involved in brine shrimp adaptation to their extreme environments. However, the precise molecular and physiological effects of $\alpha 2-(\mathrm{KK})$ have not been entirely elucidated. I determined through immunohistochemistry that my initial hypothesis that the NKA may be expressed apically in the gut epithelia was wrong. However, further exploration of the brine shrimp showed that the salt regulation organ, metepipodites, have distinct NKA expression and cell morphology. I also identified RNA expression of the $\alpha 2-\mathrm{KK}$ subunit was upregulated and apparent ion affinities were altered, when brine shrimp were reared in a hypersaline environment.

KEYWORDS: Na,K-ATPase, Artemia franciscana, Salinity, Na,K,Cl-cotransporter, Chloride Cells, Metepipodites 


\title{
ALTERED NA,K-ATPASE ISOFORM EXPRESSION IN ARTEMIA FRANCISCANA IN RESPONSE TO HYPERSALINE ENVIRONMENTS
}

\author{
JESSICA L. DRENTH
}

\begin{abstract}
A Thesis Submitted in Partial
Fulfillment of the Requirements for the Degree of

\section{MASTER OF SCIENCE}

School of Biological Sciences

ILLINOIS STATE UNIVERSITY
\end{abstract}


Copyright 2017 Jessica L. Drenth 


\title{
ALTERED NA,K-ATPASE ISOFORM EXPRESSION IN ARTEMIA FRANCISCANA IN RESPONSE TO HYPERSALINE ENVIRONMENTS
}

\author{
JESSICA L. DRENTH
}

COMMITTEE MEMBERS:

Craig Gatto, Chair

Laura Vogel

Kevin Edwards 


\section{ACKNOWLEDGMENTS}

I would like to extend my heartfelt thanks to my chair, Dr. Craig Gatto, who was able to make this thesis possible. Without his faith and encouragement, I would be miles behind. His witty humor and willingness to help with every little bump I ran into made my time at ISU both humbling and invigorating. I'd also like to thank my lab mate Kevin Stanley, who taught me how to be a master in less than 5 months. I think we both learned a lot from each other, and that's been my silver lining of the long hours spent in lab. I cannot neglect to thank the members of my committee, Laura Vogel and Kevin Edwards, who offered their time, advice, and guidance to me whenever I sought it. Their wisdom has proven invaluable to me as I complete my thesis work.

I am thankful to my labmate Nick Seitz, who spent years listening to me, and providing his own kind of comfort to me when I needed it most. I will never forget the laughs we shared, nor the hardships we overcame. Katelyn Genenbacher and Pat Shehane were wonderful undergraduates who lent their time and bright young minds to me in the lab and I cannot thank them enough. I know they will both go far. I'd also like to mention and thank my former advisor, David Rubin, who was never short on reassuring words. I am eternally grateful to have known such a kindhearted soul.

I would love to thank my husband, who saw me very little in the last several months in Illinois and yet who loved me no less. My parents too were immensely supportive, and showed me just how strong I can be. I also thank my friend Melanie, my brother, Michael, and his wife Cassie, for brightening my life and visiting me in a land where vacations ought not to be spent.

I know I am tremendously lucky to have had all of these amazing people in my life, so thanks for all the laughs, hugs, tears, words, and time. 


\section{CONTENTS}

Page

ACKNOWLEDGMENTS $\quad$ i

CONTENTS

TABLES

FIGURES $\quad$ v

CHAPTER I: INTRODUCTION 1

$\mathrm{Na}, \mathrm{K}-\mathrm{ATPase} \quad 1$

Role of Na,K-ATPase in adaptation to salt water 2

Physiology of salt tolerance in Artemia franciscana 5

Double lysine mutation in the $\alpha 2$ form of Na,K ATP-ase in brine shrimp $\quad 7$

NKA's role in the mechanism of osmoregulation in brine shrimp 8

CHAPTER II: MATERIALS AND METHODS 9

Brine Shrimp Rearing and Maintenance $\quad 9$

Tissue Fixing and Sectioning $\quad 9$

$\begin{array}{ll}\text { Staining and Imaging } & 10\end{array}$

$\begin{array}{ll}\text { NKA purification and activity from brine shrimp } & 10\end{array}$

$\begin{array}{ll}\text { RNA Extraction and RT-PCR } & 12\end{array}$

$\begin{array}{lr}\text { Real time quantitative PCR } & 12\end{array}$

$\begin{array}{ll}\text { Bumetanide treatment assay } & 13\end{array}$

$\begin{array}{lr}\text { Western Blot } & 14\end{array}$

$\begin{array}{ll}\text { CHAPTER III: RESULTS } & 15\end{array}$ 
Localization of NKA in the brine shrimp $\quad 15$

$\begin{array}{ll}\text { Cell morphology in the metepipodites } & 15\end{array}$

$\begin{array}{ll}\text { Expression of } 2 \text { forms of NKA in brine shrimp } & 18\end{array}$

$\begin{array}{ll}\text { NKCC inhibition } & 18\end{array}$

$\begin{array}{ll}\text { Ion affinities of ouabain-sensitive purified membrane fractions } & 19\end{array}$

Relative gene expression of NKA as a consequence of salt adaptation 25

$\begin{array}{ll}\text { CHAPTER IV: DISCUSSION } & 27\end{array}$

Expression of the $\alpha$-subunit of the Na,K ATPase as an adaptation to salinity 27

Metepipodites are $\mathrm{Na}^{+}$and $\mathrm{Cl}^{-}$excreting organs $\quad 29$

Altered ion affinity of NKA in hypersaline adapted brine shrimp 30

Proposed mechanism of salt extrusion in highly saline environments 31

CHAPTER V: CONCLUSION 33

$\begin{array}{ll}\text { REFERENCES } & 35\end{array}$

$\begin{array}{ll}\text { APPENDIX A: SOLUTIONS } & 38\end{array}$ 


\section{TABLES}

Table $\quad$ Page

1. Primers for RT-qPCR of the a1(NN) and a2(KK) subunits 


\section{FIGURES}

Figure $\quad$ Page

1. Post-Albers scheme of the catalytic cycle of NKA 2

2. Simplified diagram of ion transport in the teleost gill epithelium 4

3. Metepipodites of an adult brine shrimp, adapted to $2 \mathrm{M} \mathrm{NaCl}$ conditions 6

4. Immunolocalization of NKA on the membrane of gut epithelial cells 16

5. Staining of mitochondria and membranes of epipodite sections 17

6. Immunolocalization of NKA in the metepipodites of brine shrimp 20

7. Western blot of NKA from brine shrimp adapted to $2 \mathrm{M}$ or $250 \mathrm{mM} \mathrm{NaCl} 21$

8. Dose response of bumetanide in $2 \mathrm{M}$ or $250 \mathrm{mM}$ adapted brine shrimp 22

9. Comparison of water loss in brine shrimp telsons after bumetanide exposure 23

10. $\left[\mathrm{Na}^{+}\right]$and $\left[\mathrm{K}^{+}\right]$Dependence of NKA from brine shrimp 24

11. qPCR amplification plots of a1(NN) and a2(KK) subunits 26 


\section{CHAPTER I: INTRODUCTION}

\section{NA,K-ATPase}

$\mathrm{Na}, \mathrm{K}-\mathrm{ATPase}(\mathrm{NKA})$ is a plasma membrane (PM) bound transporter which shuttles 3 $\mathrm{Na}^{+}$out of the cell and $2 \mathrm{~K}^{+}$in, at the expense of 1 molecule of ATP. This 3:2:1 stoichiometry is seen in all orthologs of the NKA. This transporter is a member of the P-type ATPase superfamily of membrane pumps which is phosphorylated at a conserved aspartic acid (DKTG) within the phosphorylation domain of the pump structure ${ }^{1}$. The NKA is a heterotrimeric protein composed of three subunits, a catalytic $\alpha$-subunit, a regulatory trafficking $\beta$-subunit, and a tissuespecific auxiliary FXYD subunit ${ }^{2}$. The reaction mechanism of the NKA proceeds through a series of phosphorylated and dephosphorylated conformational states with cations bound and unbound, demonstrated by the Post-Albers scheme (Fig. 1). When the ion binding sites are intracellularly open (E1) the enzyme is bound by ATP and poised to bind $\mathrm{Na}^{+}$in the forward direction. Once $3 \mathrm{Na}^{+}$ions bind and become occluded, the conserved aspartate becomes phosphorylated by ATP with the concomitant release of ADP during the conformational transition from E1 to E1P. Following a spontaneous conformational change, the NKA opens extracellularly with a substantially lower affinity for $\mathrm{Na}^{+}$which results in extracellular $\mathrm{Na}^{+}$ release and the switch to the E2P conformation. Once extracellularly open with empty binding sites, $2 \mathrm{~K}^{+}$ions bind and expose the catalytic aspartylphosphoanhydride to nucleophilic attack by $\mathrm{H}_{2} \mathrm{O}$, thus dephosphorylating the NKA and occluding $\mathrm{K}^{+}\left(\mathrm{E} 2\left[2 \mathrm{~K}^{+}\right]\right)$. The final conformational change and deocclusion of $\mathrm{K}^{+}$intracellularly is the rate-limiting step of the cycle, but can be accelerated substantially by low affinity binding of ATP, forming E1 with ATP bound to begin another cycle ${ }^{1}$. 


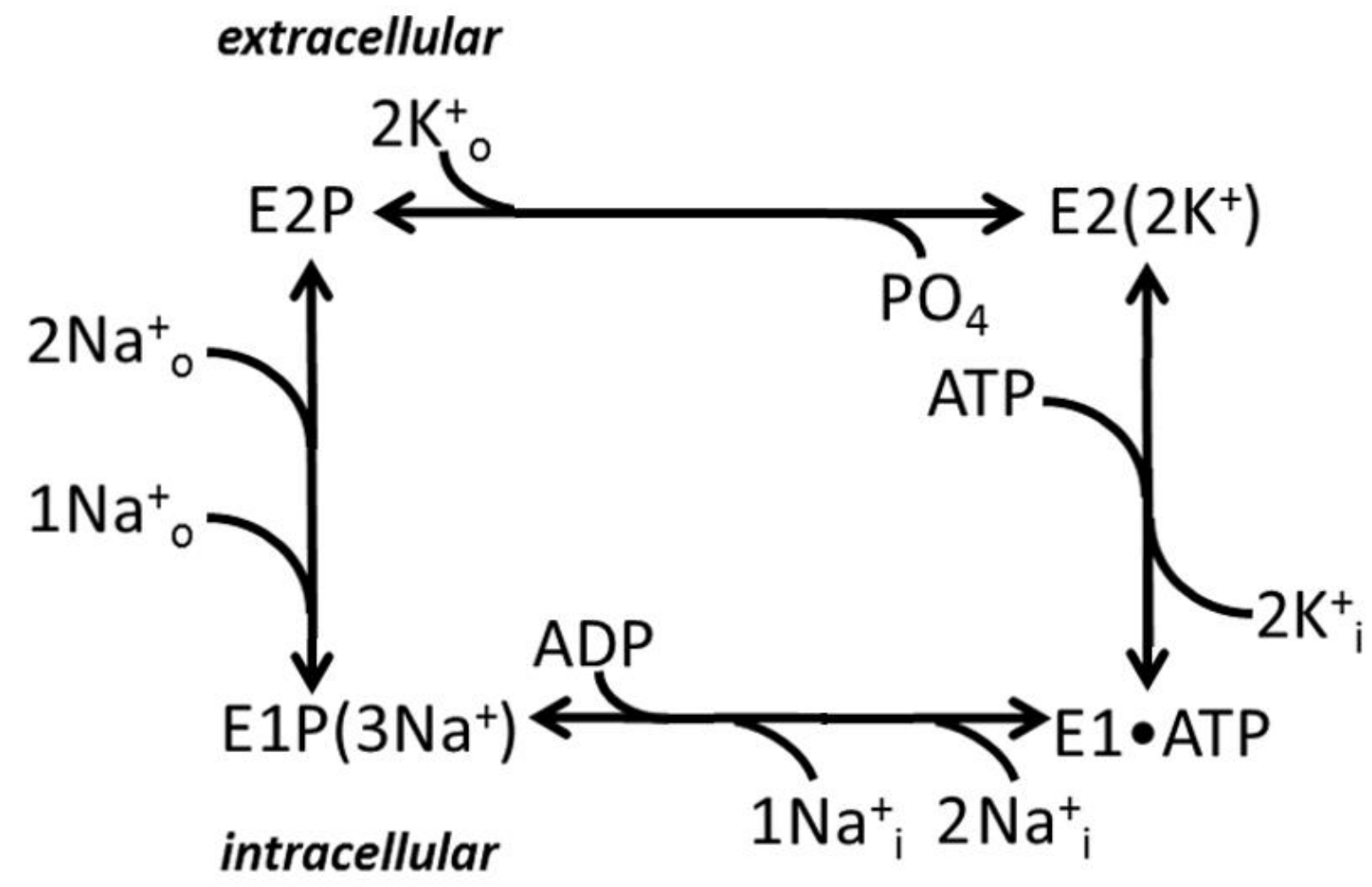

Figure 1. Post-Albers scheme of the catalytic cycle of NKA. The enzyme progresses through E1 and E2 states as the cycle proceeds to pump $3 \mathrm{Na}^{+}$out of the cell (extracellular space) and brings $2 \mathrm{~K}^{+}$into the cytoplasmic side.

\section{Role of Na,K-ATPase in adaptation to salt water}

The NKA plays an important role in the osmoregulation of marine animals, in particular Fundulus heteroclitus (teleost fishes, bony fishes) ${ }^{3}$. Teleost fish gills have been studied extensively for their ability to extrude $\mathrm{Na}^{+}$and $\mathrm{Cl}^{-}$from the gills directly into the surrounding seawater. Similarly, freshwater adapted Anguilla rostrata (American eels) have been shown to extrude $\mathrm{Na}^{+}$into the surrounding environment in combination with increased NKA activity, 
when exposed to saltwater ${ }^{3}$. When the NKA exclusive inhibitor (ouabain) was applied to American eels, there was a $90 \%$ decrease in $\mathrm{Na}^{+}$efflux in the gills compared to control ${ }^{3}$. Additional adaptations for $\mathrm{Na}^{+}$extrusion are the single-stranded tight junctions found between adjacent chloride cells and accessory cells of fish gill epithelia ${ }^{4}$. Tight junctions are multistranded with high electrical resistance, preventing passive ion diffusion, with the exception of fish gill epithelia ${ }^{4}$. $\mathrm{Na}^{+}$efflux in teleost fishes has been shown to be inhibited by a paracellular cation shunt inhibitor, 2,4,6-triaminopyrimidine (TAP), across the opercular epithelium in isolated preparations ${ }^{4}$.

Net loss of $\mathrm{Na}^{+}$, in teleost fish, is achieved mainly in specialized cells of the gill epithelium called chloride cells ${ }^{3}$. These cells are characterized by their high mitochondrial content and excess surface area of the basolateral membrane ${ }^{5}$. Within the basolateral membrane of these chloride cells, ion regulation occurs in part by the NKA establishing a steep $\mathrm{Na}^{+}$ gradient used by a series of secondary active transporters. Of these secondary active transporters, the $\mathrm{Na}^{+}, \mathrm{K}^{+}, 2 \mathrm{Cl}^{-} \mathrm{Co}$-transporter (NKCC) utilizes this $\mathrm{Na}^{+}$gradient to import $\mathrm{K}^{+}$and $\mathrm{Cl}^{-}$from the hemolymph into the epithelial chloride cell ${ }^{5}$. Apically, $\mathrm{Cl}^{-}$leaves the cell via facilitated diffusion through a Cystic fibrosis transmembrane conductance regulator (CFTR)-like channel. The excess excretion of $\mathrm{Cl}^{-}$creates a positive trans-epithelial potential (TEP), which drives $\mathrm{Na}^{+}$extrusion from the body through specialized low-resistance single-stranded tight junctions (Fig. 2) ${ }^{6,7}$. Near these single-stranded tight junctions there is also an accumulation of $\mathrm{Na}^{+}$due to a tapering of the passage between lateral membranes of connected cells, which further facilitates $\mathrm{Na}^{+}$extrusion out of the body. 


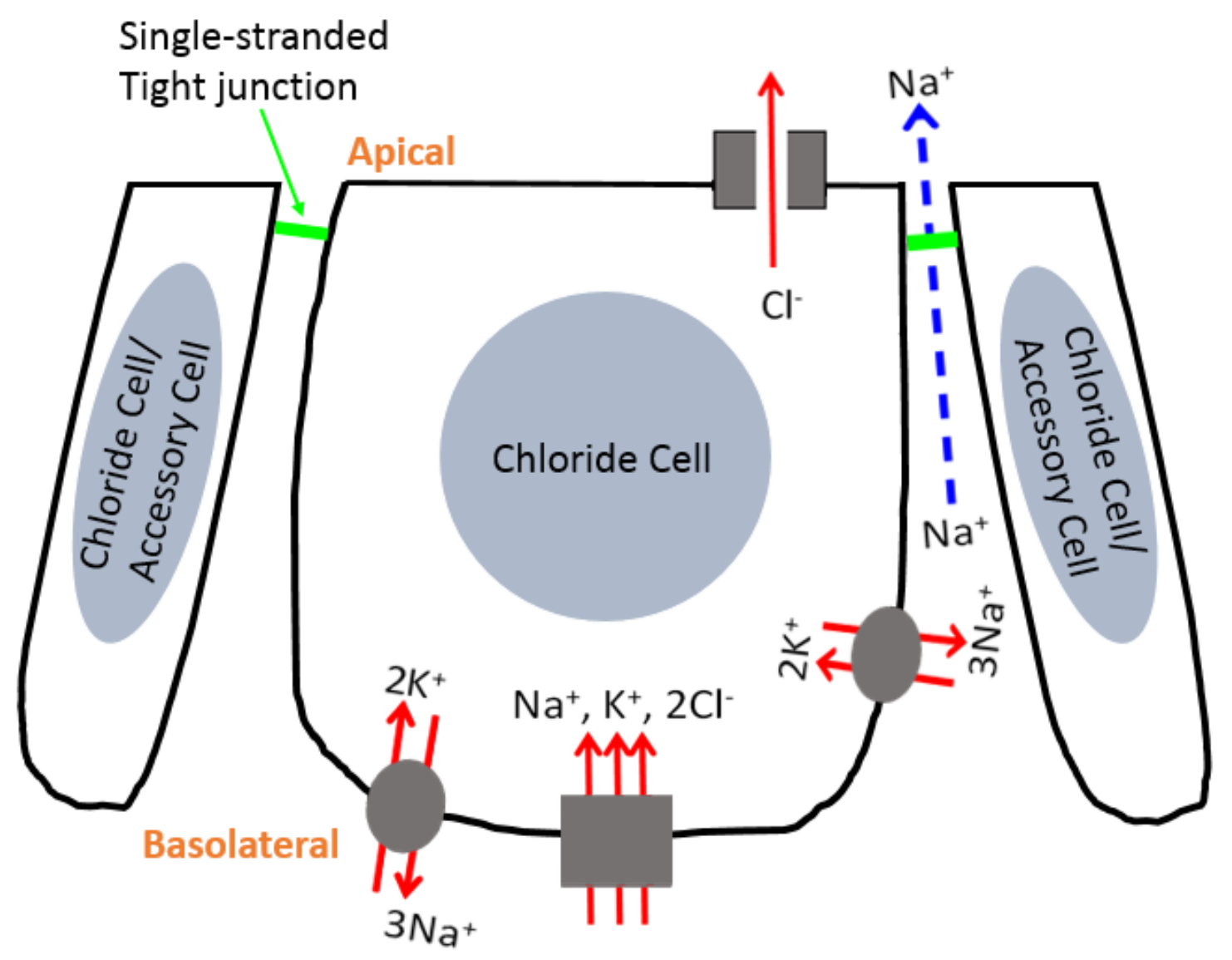

Figure 2. Simplified diagram of ion transport in the teleost gill epithelium. In the basolateral membrane the NKA establishes a $\mathrm{Na}^{+}$gradient and works in concert with the NKCC to import $\mathrm{Cl}^{-}$into the cell from the hemolymph. Once inside the chloride cell, $\mathrm{Cl}^{-}$is exported from the body through CFTR-channels, in doing so establishes a positive TEP. The positive TEP is then used to extrude $\mathrm{Na}^{+}$through a paracellular single-pass tight junction in a passive manner. 


\section{Physiology of salt tolerance in Artemia franciscana}

Artemia franciscana (brine shrimp) are unique in their ability and adaptations to tolerate extreme salinities, even up to concentrations as high as $4 \mathrm{M} \mathrm{NaCl}^{8}$. One adaptation is a cuticle impregnable to the surrounding medium, allowing for strict ionic and osmotic intake control via the gut through active swallowing ${ }^{9}$. As such, in hypersaline environments large amounts of $\mathrm{Na}^{+}$ are passively absorbed into the gut epithelial cells and actively pumped into the hemolymph via the basolateral NKA ${ }^{9}$. Although these organisms absorb large quantities of $\mathrm{Na}^{+}$from an environment 100-times more concentrated externally than internally, the internal hemolymph only increases 6-fold in osmotic pressure when compared to an isosmotic environment ${ }^{9}$. However, in nauplii (or juvenile) stage, $\mathrm{Na}^{+}$and $\mathrm{Cl}^{-}$excretion occurs at a special neck organ known as the salt gland or maxillary gland ${ }^{8}$. Upon reaching adulthood, this organ disappears and excretion occurs in metepipodites, organs attached to the swimming legs (phyllopodia) (Fig. 3) ${ }^{10}$.

These brine shrimp metepipodites may have functional convergence with the aforementioned gills of teleost fishes with regard to their chloride cells ${ }^{11}$. One key morphological characteristic of these chloride cells is that they are rich in mitochondria, another adaptation to saline environments ${ }^{11}$. In brine shrimp, $\mathrm{Cl}^{-}$is far from its electrochemical equilibrium across the apical membrane, internally (hemolymph) vs. externally (gut), suggesting it is actively transported out of the organism ${ }^{11}$. On the other hand, $\mathrm{Na}^{+}$is close in equilibrium to its electrochemical gradient across the body wall, and localized pockets of higher electrical potentials (aided, in part by the positive TEP generated by $\mathrm{Cl}^{-}$exit) must exist where $\mathrm{Na}^{+}$is excreted passively along its electrochemical gradient, as is the case in teleost fishes ${ }^{6,11,12}$ The chloride cells of fish gills are notable in that they form a crypt on the apical membrane shared by other chloride cells or accessory cells. These crypts serve as regions of concentrated $\mathrm{Na}^{+}$and 
electrical current across the epithelia, in part driving $\mathrm{Cl}^{-}$secretion ${ }^{13}$. There is evidence for the metepipodites having high permeability to chloride ions, and show differential localization of $\mathrm{Cl}^{-}$ permeability at the apical surface of the metepipodites ${ }^{11}$.

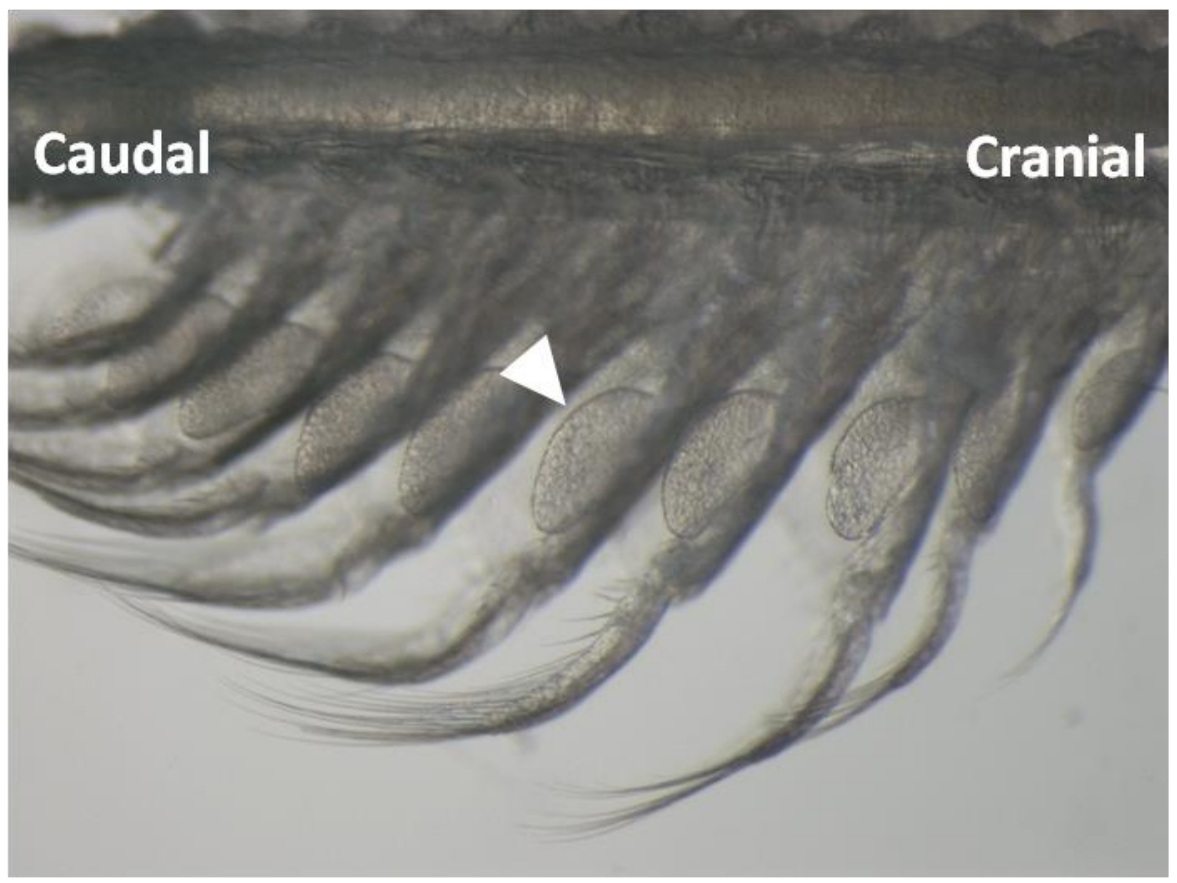

Figure 3. Metepipodites of an adult brine shrimp, adapted to $2 \mathrm{M} \mathrm{NaCl}$ conditions. Right side is cranial, left is caudal. Arrow indicates a metepipodite on a phyllopodia. 


\section{Double lysine mutation in the $\alpha 2$ form of Na,K ATP-ase in brine shrimp}

Brine shrimp have 2 isoforms of the NKA, a constitutively expressed $\alpha 1$ and lesser expressed $\alpha 2$ which share $74 \%$ amino acid identity with different RNA expression patterns ${ }^{10}$. The $\alpha 2$ isoform has 2 distinct positively charge lysines in place of asparagine in $\alpha 1(\alpha 1(\mathrm{NN}))$ within the ion binding regions at $\mathrm{N} 324 \mathrm{~K}$ and $\mathrm{N} 776 \mathrm{~K}(\alpha 2(\mathrm{KK}))$, which alter affinity and potentially stoichiometry ${ }^{10}$. This prediction stems from the thermodynamic limit of the energy released from hydrolysis the gamma phosphate of ATP. As extracellular $[\mathrm{NaCl}]$ approaches saturation, the energy provided by 1 ATP is insufficient to transport $3 \mathrm{Na}+$ ions against this gradient. Therefore to overcome the large $\mathrm{Na}^{+}$gradient it seems that the brine shrimp NKA would need to alter its canonical 3Na:2K:1ATP stoichiometry.

However, work by Jorgensen and Amat ${ }^{10}$ proposed the possibility of a reduced stoichiometry from 3Na:2K:1ATP a2(KK). This hypothesis was supported by our lab, demonstrating the $\mathrm{a} 2(\mathrm{KK})$ has a reduced stoichiometry to $2 \mathrm{Na}: 1 \mathrm{~K}: 1 \mathrm{ATP}^{14}$. While introducing either one of the lysine mutant alone displayed reduced ion affinity, when both lysine residues were introduced together (i.e. like found in endogenous a2(KK)) there appears to be a partial recovery of ion affinity ${ }^{11,14}$. Our leading hypothesis is that structurally the K324 pushes (via ionic repulsion) the epsilon amino group of K776 into one of the ion binding sites shared by both $\mathrm{Na}^{+}$and $\mathrm{K}^{+}$, thus providing a pseudo-cation constantly bound within one of the ion binding sites. Consequently, all binding sites are occupied by cations as the a2(KK) pump proceeds through the reaction cycle, but site occupied by $-\mathrm{NH}_{3}{ }^{+}$of $\mathrm{K} 776$ is never released. It is a surrogate $\mathrm{Na}^{+}$ ion during the E1-P to E2-P transition and a surrogate $\mathrm{K}^{+}$ion during the $\mathrm{E} 1\left[2 \mathrm{~K}^{+}\right]$to $\mathrm{E} 1$ transition, thus reducing the number of $\mathrm{Na}^{+}$and $\mathrm{K}^{+}$ions required for transport by $1 \mathrm{each}^{14}$. 


\section{NKA's role in the mechanism of osmoregulation in brine shrimp}

In marine teleosts fishes, the NKA is known to function as part of the gill's salt regulatory physiology, establishing the $\mathrm{Na}^{+}$gradient for the $\mathrm{NKCC}$ to use for the import of $\mathrm{Cl}$ from the hemolymph to eventually be secreted out of the body by the CFTR-channel ${ }^{6}$. This same mechanism may be used analogously in the metepipodites of brine shrimp ${ }^{11}$. This mechanism in combination with the NKA $\alpha 2(\mathrm{KK})$ with a reduced stoichiometry may play a pivotal role in the ability for brine shrimp to survive in such harsh environments. However, the localization of the $\alpha 2(\mathrm{KK})$ remains unknown, but one such location may be on the apical membrane of the gut epithelium (i.e. immediate $\mathrm{Na}^{+}$extrusion upon passive entry into the gut epithelial cells). However, the location and function is more likely similar to the known physiology of salt secretion in the gills of marine teleost fish.

In this work, I attempted to elucidate differences in the localization and expression of $A$. fransiscana NKA between hypersaline and saline adapted animals. Throughout my work, I identified; (i) The NKA is only found on the basolateral surface, rather than apical, in the brine shrimp gut epithelia. (ii) There exists adaptations within the osmoregulatory salt organs, metepipodites, in hypersaline adapted animals similar to those found in the chloride cells of teleost fishes. (iii) Total RNA of both $\alpha 1$ and $\alpha 2$, identified an increased expression of $\alpha 2$ in hypersaline adapted animals. (iv) Variable ion affinities of the NKA was demonstrated between hypersaline and saline adapted animals. My work here provides further insight into how the differential localization and expression of the NKA help A. fransiscana adapt and survive in such harsh environments. 


\section{CHAPTER II: MATERIALS AND METHODS}

\section{Brine Shrimp Rearing and Maintenance}

Following the manufactures protocol, approximately 225,000 nauplii ( $1 \mathrm{~g}$ of brine shrimp cysts), were hatched in $1 \mathrm{~L}$ of $1 \mathrm{X}$ instant ocean artificial sea water (SW) with vigorous aeration and constant light for 24 hours. After hatching, nauplii were divided and reared in separate aquariums with either low salt $(0.5 \mathrm{X} \mathrm{SW}, \sim 250 \mathrm{mM} \mathrm{NaCl})$ and high salt (1X SW with additional $1.5 \mathrm{M} \mathrm{NaCl}$, final $[\mathrm{NaCl}] \sim 2 \mathrm{M})$. Aquariums were maintained at $26-28^{\circ} \mathrm{C}$ under continuous light with aeration provided near the surface for $\mathrm{O}_{2}$ supply. Feeding began 12 hours post-hatching with spirulina algal powder. Once reaching adulthood, animals were fed every other day.

\section{Tissue Fixing and Sectioning}

Adult brine shrimp in each condition were collected and fixed in $4 \%$ paraformaldehyde (PFA) until processing (minimum fixation 12 hours). Dehydration occurred through a series of alcohol washes beginning with $25 \%, 50 \%, 75 \%$ and completed in two washes in $100 \%$ ethanol. Upon dehydration, tissue was cleared with histoclear medium prior to paraffin embedding (graded series of histoclear:paraffin). Paraffin embedding was performed at $58^{\circ} \mathrm{C}-60^{\circ} \mathrm{C}$ to maintain paraffin in its liquid state. Tissue was transferred to a mold filled with liquid paraffin and solidified on dry ice for 15-20 minutes in preparation for sectioning. Individual sections were cut in $20 \mu \mathrm{m}$ increments and transferred to poly-L-lysine coated slides, heated at $58^{\circ} \mathrm{C}$ for 20 minutes and stored at room temp (RT) ${ }^{15}$. 


\section{Staining and Imaging}

Paraffin sectioned slides were incubated in the following order for 10 minutes each: $3 \mathrm{X}$ in $100 \%$ histoclear, $3 \mathrm{X}$ in $100 \%$ ethanol and then rehydrated stepwise in $80 \%$ Ethanol, $50 \%$ ethanol, and finally ddH2O. Slides were then treated at $90-95^{\circ} \mathrm{C}$ for $15-20$ minutes in sodium citrate buffer for antigen unmasking and then rinsed in $\mathrm{dH}_{2} \mathrm{O}$. Sections were permeabilized in Tris-buffered saline $+0.1 \%$ Tween-20 (TBST) with gentle agitation for 10 minutes, then blocked for 1 hour in 10\% Bovine Serum albumin (BSA) in Tris-buffered saline TBS at RT. Primary antibody incubation occurred overnight at $4{ }^{\circ} \mathrm{C}$ with gentle agitation in TBS with $1 \%$ BSA. Primary antibodies raised in rabbit, anti-NKA $\alpha$-subunit (antibody $\alpha 5$, Developmental Studies Hybridoma Bank (DSHB)) and anti-cytochrome c oxidase (i.e. complex IV of the electron transport system in mitochondria (COX IV)) antibody (20E8C12, Abcam catalog no. ab14744), were used in 1:100 dilution. Secondary antibodies goat-anti-mouse Alexa 568 secondary antibody (Thermofisher Catalog \#A-11004), phalloidin-Alexa 488 (Thermofisher Catalog \#A12379), wheat-germ agglutinin-Alexa 488 (Thermofisher Catalog \#W11261), and/or to-pro3 (Thermofisher Catalog \#T3605) for counterstaining, were washed 3X in TBS in $0.025 \%$ triton and incubated for 1 hour at $\mathrm{RT}^{16}$. Slides were then washed $3 \mathrm{X}$ in TBS, mounted in vectashield fluormount mounting medium and imaged with a Leica Sp2 confocal microscope.

Images were imported into Adobe Photoshop to be manually assembled for labelling, overlays, and max projections in RGB format, with levels adjusted as needed for clarity.

\section{NKA purification and activity from brine shrimp}

Purification of the NKA from adult brine shrimp was carried out as described by Peterson et al. 1978 , with modifications ${ }^{16}$. Homogenizations and resuspensions were performed on ice 
while spins were performed at $4{ }^{\circ} \mathrm{C}$. Brine shrimp were homogenized using a Beckman dounce homogenizer in buffer HS (1X protease inhibitor, $250 \mathrm{mM}$ sucrose, $25 \mathrm{mM}$ Imidazole, $1 \mathrm{mM}$ EDTA pH 7.4) and spun at $500 \times \mathrm{g}$ for 5 minutes. Supernatant was collected and the pellet was resuspended in one half of the starting volume of buffer HS and spun for an additional 5 minutes at $500 \times \mathrm{x}$. Total supernatant was amalgamated and spun at $1000 \mathrm{x} g$ for 15 minutes, and the supernatant fraction was collected and remaining pellet was resuspended in $1 / 4$ of the initial volume and re-spun at $1000 \times \mathrm{x}$ for 15 minutes. Both supernatants from the $1000 \mathrm{x} g$ spin were pooled and spun at 27,000 $\mathrm{x} g$ for 2 hours. The final supernatant was removed and the pellet was resuspended in buffer HS.

Protein concentration was determined via Bradford assay as previously described ${ }^{18}$, and then NKA activity, along with $\left[\mathrm{Na}^{+}\right]$and $\left[\mathrm{K}^{+}\right]$dependence (i.e. apparent affinity $\left(\mathrm{K}_{0.5}\right)$ ) were assessed using a colorimetric ATPase assay ${ }^{19}$. To determine the $\mathrm{K}_{0.5}$ for $\left[\mathrm{Na}^{+}\right]$and $\left[\mathrm{K}^{+}\right]$in enzyme preparation, protein was added in triplicate with ATPase solution (2.4mM EGTA, 14.5mM $\mathrm{MgCl}_{2}, 16 \mathrm{mM}$ Tris $2 \mathrm{ATP}, 239.5 \mathrm{mM}$ imidazole, $\mathrm{pH}$ 7.2) in either increasing $\left[\mathrm{Na}^{+}\right]$with constant $24.5 \mathrm{mM} \mathrm{KCl}$ (for the $\mathrm{K}_{0.5}$ of $\mathrm{Na}^{+}$), or increasing $\left[\mathrm{K}^{+}\right]$with constant $135 \mathrm{mM} \mathrm{NaCl}$ (for the $\mathrm{K}_{0.5}$ of $\mathrm{K}^{+}$), with and without ouabain. The final volume of each well was brought up with $50 \mathrm{mM}$ Tris buffer ( $\mathrm{pH} 7.4)$, then incubated $37^{\circ} \mathrm{C}$ for 15 minutes. The enzyme reaction was stopped in stopping solution $\left(2 \mathrm{ml} \mathrm{H}_{2} \mathrm{O}, 2 \mathrm{ml} \mathrm{1M} \mathrm{HCl,} \mathrm{0.13g} \mathrm{Absorbic} \mathrm{acid,} \mathrm{200 \mu L} \mathrm{10 \%}\right.$ $\mathrm{NH}_{4} \mathrm{MoO}_{4}$ ), brought up with ACG solution (2\% Na-arsenite, 2\% Na-citrate, 24mM Glacial acetic acid), incubated for additional 5 minutes at $37^{\circ} \mathrm{C}$ and read at $800 \mathrm{~nm}$. 


\section{RNA Extraction and RT-PCR}

RNA isolation was performed using Trizol reagent according to the manufacturer's directions (TRIZOL Catalog No. 15596). Briefly, samples were homogenized in $600 \mu \mathrm{L}$ of trizol in a Beckman dounce homogenizer. Insoluble material was removed with a 12,000 x $g$ spin for 10 minutes at $4^{\circ} \mathrm{C}$. Samples were incubated at RT for 10 minutes and directly following, chloroform was added, equal to $20 \%$ of the starting volume of trizol. Tubes were shaken and incubated for 3 minutes at RT and spun at $12,000 \times g$ for 15 minutes at $4^{\circ} \mathrm{C}$. The aqueous phase was removed and pipetted into a new microcentrifuge tube with isopropyl alcohol added, equal to $50 \%$ of the starting amount of trizol. Sample was vortexed and centrifuged at 7,500 x $g$ for 5 minutes at $4^{\circ} \mathrm{C}$, supernatant was then discarded and pellet was left to air dry for 10-15 minutes, and resuspended in RNase free $\mathrm{dH}_{2} \mathrm{O}$. Quantitation was determined using a nanodrop spectrophotometer.

Reverse transcription reaction was performed with equal amounts of RNA and HighCapacity cDNA RT kit master mix (Applied biosystems catalog no. 4368814) consisting of 10x RT buffer, 25x dNTP mix, 10x random primers, reverse transcriptase enzyme, and dH2O. Reaction was run in a thermocycler for the following steps: $25^{\circ} \mathrm{C}$ for 10 minutes, $37^{\circ} \mathrm{C}$ for 120 minutes, $85^{\circ} \mathrm{C}$ for 5 minutes, $4^{\circ} \mathrm{C}$ hold. Following quantitation was determined using a nanodrop spectrophotometer and the cDNA was stored at $-20^{\circ} \mathrm{C}$ until qRT-PCR was performed.

\section{Real time quantitative PCR}

Primers were designed at regions of dissimilarity between the $\alpha 1$ and $\alpha 2$ isoforms to prevent nonspecific amplification (Table 1). Quantitative real-time PCR was performed with cDNA and SYBR green master mix containing SYBR green dye, AmpliTaq Gold DNA 
polymerase, dNTPS with dUTP, passive reference dye and buffer components (Applied Biosystems, catalog \#4309155). Standard curves were created in a series of four 10-fold dilutions in a $50 \mu \mathrm{L}$ reaction volume, run in triplicate. Primers were added at a concentration of $15 \mu \mathrm{M}$ and template DNA was added from a $2000 \mu \mathrm{g} / \mathrm{ml}$ stock cDNA prep. The reactions were read in an Applied Biosystems 7300 Real Time PCR System under the following conditions: 2 minutes at $50^{\circ} \mathrm{C}$ for 1 cycle, 10 minutes at $95^{\circ} \mathrm{C}$ for 1 cycle, 40 cycles of $95^{\circ} \mathrm{C}$ for $15 \mathrm{~s}, 60^{\circ} \mathrm{C}$ or $30 \mathrm{~s}, 72^{\circ} \mathrm{C}$ for $30 \mathrm{~s}$, and finally 10 minutes at $72^{\circ} \mathrm{C}$ for 1 cycle.

\section{Bumetanide treatment assay}

Bumetanide stock solution $(100 \mathrm{mM})$ was prepared in DMSO and added to $10 \mathrm{mls}$ of artificial sea water $/ \mathrm{NaCl}$ mixtures depending on rearing conditions to treatment concentrations of $25,50,75$, and $100 \mu \mathrm{M}$ bumetanide, with a control using a matching [DMSO]. Brine shrimp were added to 6-well tissue culture wells in each respective treatment dosage of bumetanide diluted at room temperature for 24 hours and then assayed for the response to bumetanide. Responses were scored as either no effect, or significantly impaired swimming/lethality. 
Table 1. Primers for RT-qPCR of the a1(NN) and a2(KK) subunits

\begin{tabular}{|c|c|c|c|}
\hline Gene & Accession \# & Primer sequence & $\begin{array}{l}\text { Amplicon } \\
\text { size (bp) }\end{array}$ \\
\hline $\begin{array}{l}\alpha 1(\mathrm{NN}) \text { subunit of } \\
\mathrm{Na}, \mathrm{K}-\mathrm{ATPase}\end{array}$ & X56650.1 & $\begin{array}{l}\text { F: 5'-CAGAGGAATTGAAAGAGGCC-3' } \\
\text { R: 5'-AGCCCAGCAAATCTCAATCC-3' }\end{array}$ & 172 \\
\hline $\begin{array}{l}\alpha 2(\mathrm{kk}) \text { subunit of } \\
\mathrm{Na}, \mathrm{K} \text {-ATPase }\end{array}$ & P17326.1 & $\begin{array}{l}\text { F: 5'-AAAATTGTCACAGCAGACACC-3' } \\
\text { R: 5'-GACCCAGTTGACATCTCTGC-3' }\end{array}$ & 193 \\
\hline \multirow{2}{*}{ Tubulin $\alpha$-chain } & AF078670.1 & $\begin{array}{l}\text { F: 5'-GACAAATCGATTGGTGGAGG-3' } \\
\text { R: } 5 \text { '-CCACGGGCATAGTTGTTAGC-3' }\end{array}$ & 203 \\
\hline & & $\begin{array}{l}\text { F: 5'-GGTACCGGATCTGGGTTCAC-3' } \\
\text { R: 5'-ATAGATGGCCTCGTTGTCG-3' }\end{array}$ & 202 \\
\hline
\end{tabular}

\section{Western Blot}

A $7.5 \%$ polyacrylamide gel was run with 40 ug amounts of both membrane purified highand low-salt brine shrimp treatment groups with 0.5ug purified Na,K-ATPase from sheep kidney for control. The transfer occurred on PVDF membrane in 10mM CAPS, $10 \%$ methanol for 3 hours at 180mA using a bioRad blot system. The membrane was then was blocked with soy milk for 10 minutes at RT. The blot was rinsed $3 \mathrm{X}$ in PBST and then incubated overnight at $4{ }^{\circ} \mathrm{C}$ with 1:1000 mouse-anti-NKA IgG Following primary antibody incubation, the blot was washed $3 \mathrm{X}$ in PBST at RT and then incubated with 1:5000 goat-anti-mouse IgG HRP-conjugate for 1 hour at room temperature. Following secondary antibody incubation, blot was washed $3 \mathrm{X}$ in PBST at RT and incubated with chemiluminescent substrate (ThermoFisher Scientific SuperSignalTM West Pico Chemiluminescent Substrate catalog no. 34080) for 5 minutes then imaged with a geldoc system. 


\section{CHAPTER III: RESULTS}

\section{Localization of NKA in the brine shrimp}

In order to determine the cellular membrane localization of the NKA in brine shrimp gut epithelia, immunohistochemical analysis was performed on adult tissue sections. Using an antibody against avian NKA $\alpha$-subunit (antibody $\alpha 5$, DSHB) I labeled transverse sections of adult brine shrimp gut epithelia and the resulting images revealed distinct and consistent basolateral localization in both $2 \mathrm{M}$ and $250 \mathrm{mM}$ total NaCl-reared brine shrimp (Fig. 4A and 4C). Staining for F-actin identified the boundaries of the cell membrane, providing a clear picture of NKA within the epithelial layer of the gut (Figs 4B and 4D). F-actin staining wasn't typical and likely due to the treatment of the tissue or the characteristics of brine shrimp actin, however the stain still revealed the extent of the cells boundaries.

\section{Cell morphology in the metepipodites}

I immunostained the legs in an attempt to identify morphological differences between cell types (i.e. phyllopodia vs. metepipodites), however initially identified similar nuclei content in both metepipodites and phyllopodia (Fig 5C). The next logical step was to attempt to identify whether mitochondrial differences exist between these cells. Using an anti-COX IV antibody, a membrane bound mitochondrial protein in the electron-transport chain, and observed significant differences between the two cell types. The metepipodites were clearly identifiable due to the excess mitochondrial content compared to surrounding phyllopodia (Fig. 5B). Additionally, wheat germ agglutinin staining (WGA), which stains membrane-associated sugars, revealed an altered membrane architecture in the metepipodites relative to the phyllopodia, in part due to the amount of mitochondria present within these cells (Fig 5A, 5D, and 5E). It isn't clear if the 
increased signal in the metepipodites is due to membrane amplification or altered membrane sugars.

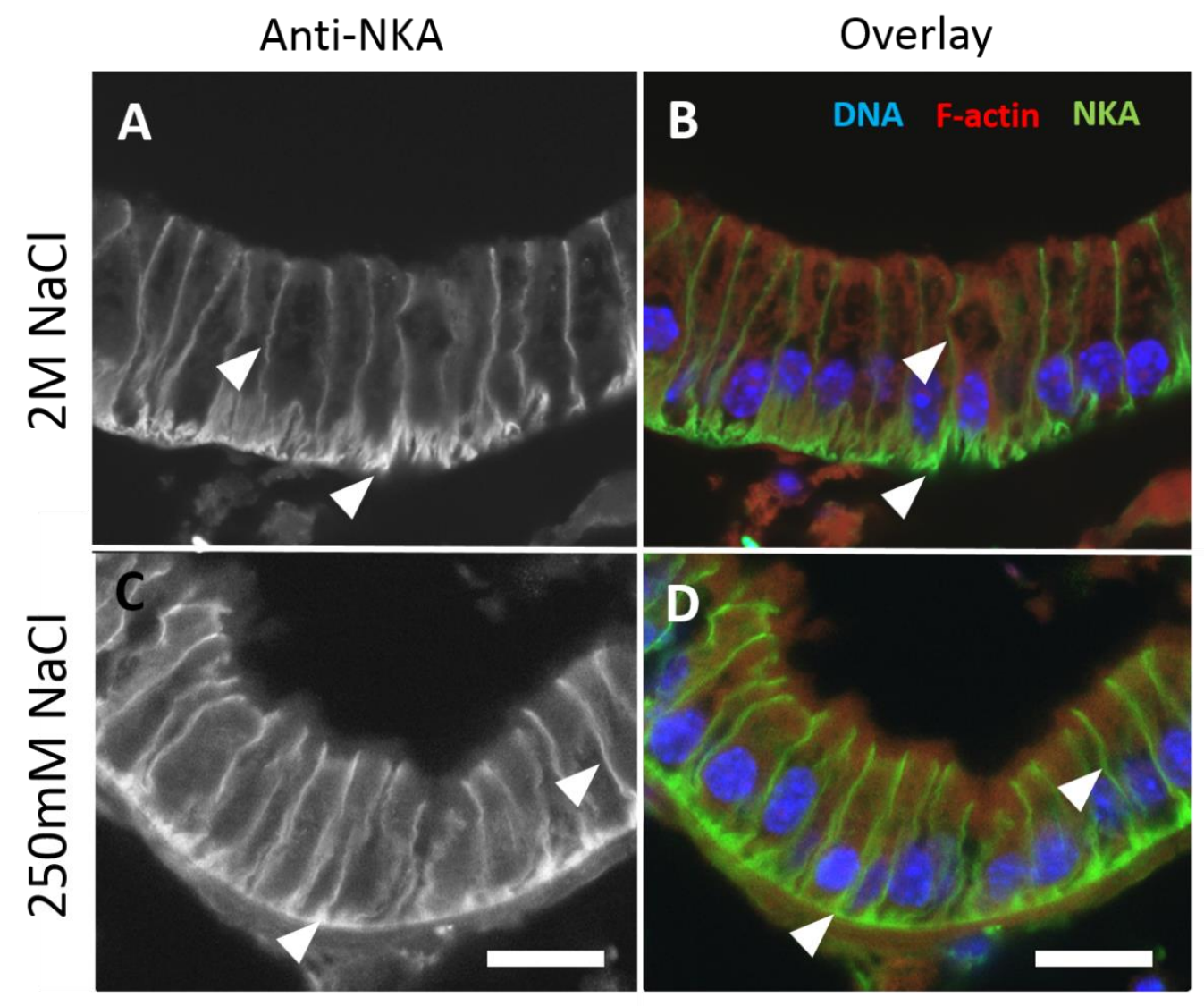

Figure 4. Immunolocalization of NKA on the membrane of gut epithelial cells. With staining for NKA (green), F-actin (red), and DNA (blue), and scale bar representing $20 \mu \mathrm{m}$. A,B) $2 \mathrm{M} \mathrm{NaCl}$ adapted brine shrimp epithelial cells showing NKA localization in the basolateral membrane. C,D) $250 \mathrm{mM} \mathrm{NaCl}$ adapted brine shrimp epithelial cells showing NKA localization in the basolateral membrane. 


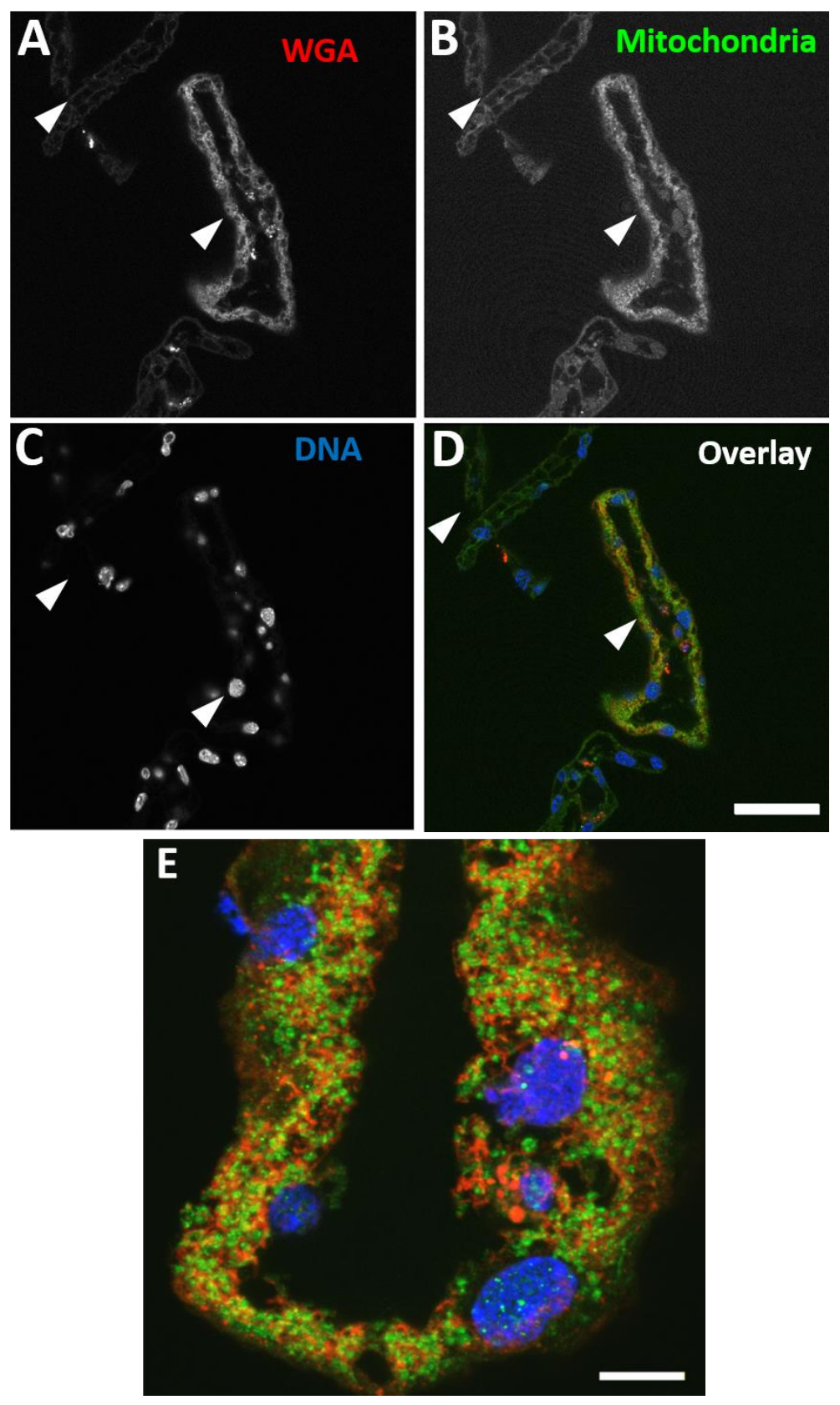

Figure 5. Staining of mitochondria and membranes of epipodite sections. Stained for

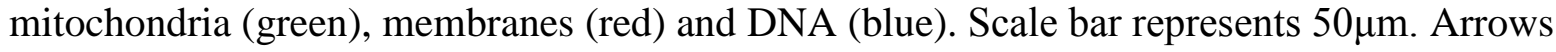
indicate tissue sections from metepipodites and phyllopodia. A) WGA staining only. B) Mitochondria staining only. C) DNA stain only. D) Overlayed metepipodite image. E) Overlayed image of metepipodite, scale bar represents $10 \mu \mathrm{m}$. 
Initial staining of the metepipodites demonstrated the NKA expression, again localized the basolateral membrane, indicating that the NKA is pumping $\mathrm{Na}^{+}$into the hemolymph space and not directly out of the organism as hypothesized. This indicates that the a2(KK) form of the subunit is not being used to adapt to extreme salinities by differential membrane localization. Instead, the metepipodites appear to have a highly amplified basolateral membrane, as indicated by the extent of NKA staining (Fig. 6). Staining for the apical membrane and basolateral membrane was attempted with an anti-Drosophila crumbs antibody (DSHB, Cq4) and an antiDrosophila discs-large antibody (DSHB, 4f3), respectively. Staining was not successful. Additional staining for the apical membrane $\mathrm{Cl}^{-}$channel was attempted using anti-rabbit CFTR antibody (Abbiotec, 200186) however this was also unsuccessful.

\section{Expression of 2 forms of NKA in brine shrimp}

In order to attempt to identify the expression of two distinct $\alpha$-subunit isoforms of the NKA, a western blot of whole animal homogenate from both conditions using anti- $\alpha$ NKA antibody revealed two distinct bands between 105-110 kDa. The two bands represented both $\alpha 1(\mathrm{NN})$ and $\alpha 2(\mathrm{KK})$ isoform, based on $\mathrm{kDa}$ size and comparison to purified kidney (Fig. 7). Although protein bands were not directly analyzed, identical protein concentrations were added to each lane, revealing a darker bands in the $2 \mathrm{M} \mathrm{NaCl}$ group, as was expected based on increased expression of the NKA in response to increased salinity.

\section{NKCC inhibition}

Bumetanide, a specific inhibitor of NKCC, was added to the medium of brine shrimp adapted to $2 \mathrm{M} \mathrm{NaCl}$ and $250 \mathrm{mM} \mathrm{NaCl}^{21}$. Figure 8 shows an increase in response (i.e. reduced 
movement and/or death) to bumetanide in brine shrimp adapted to $2 \mathrm{M} \mathrm{NaCl}$ compared to those adapted to $250 \mathrm{mM} \mathrm{NaCl}$. At $50-75 \mu \mathrm{M}$ bumetanide, there was an approximate $50 \%$ response rate for the high-salt adapted brine shrimp only. Brine shrimp adapted to $250 \mathrm{mM} \mathrm{NaCl}$ did not show a dose response to bumetanide (Fig 8). Additionally, 2M adapted brine shrimp had increased water loss (Fig 9) including shrinkage and an upward tail curling which greatly inhibited movement.

\section{Ion affinities of ouabain-sensitive purified membrane fractions}

Figure 10A shows the normalized average values for the $\mathrm{K}_{0.5}$ of $\mathrm{Na}$ from brine shrimp adapted to both $2 \mathrm{M}$ and $250 \mathrm{mM} \mathrm{NaCl}$, measured by ATPase assay. There was no detectable difference in $\mathrm{K}_{0.5}$ of the NKA fractions between the 2 groups while both showed well defined curves $\left(\mathrm{R}^{2}=\right.$ 0.95 ) for both datasets. Figure $10 \mathrm{~B}$ shows the $\mathrm{K}_{0.5}$ for $\mathrm{K}^{+}$in both $250 \mathrm{mM}$ and $2 \mathrm{M}$ adapted brine shrimp. The $\mathrm{K}_{0.5}$ of the $250 \mathrm{mM}$ fraction was higher than that from the $2 \mathrm{M} \mathrm{NaCl}$ fraction $(3.78 \mathrm{mM}>0.7 \mathrm{mM} \mathrm{K})$, indicating a reduced affinity for $\mathrm{K}^{+}$compared to the $2 \mathrm{M} \mathrm{NaCl}$ fraction. 


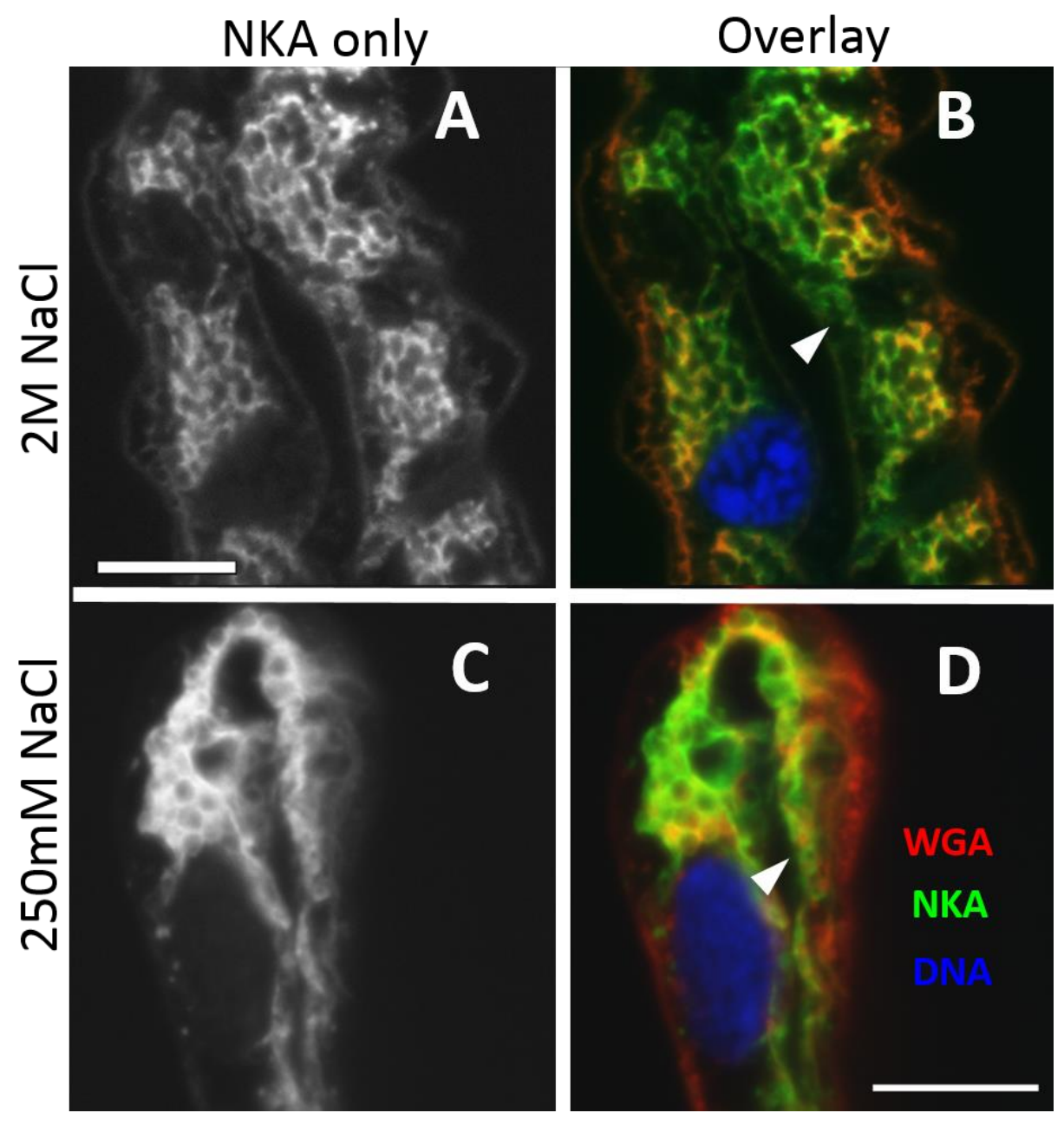

Figure 6. Immunolocalization of NKA in the metepipodites of brine shrimp. With staining for membrane (red), NKA (green) and DNA (blue). Arrows indicate the basolateral side of the metepipodite, facing the hemolymph. A, B) Brine shrimp reared in $2 \mathrm{M} \mathrm{NaCl}$, revealing NKA localized to the basolateral membrane. C,D) Brine shrimp reared in $250 \mathrm{mM} \mathrm{NaCl}$, revealing basolateral localization of NKA. Scale bar represents $10 \mu \mathrm{m}$. 


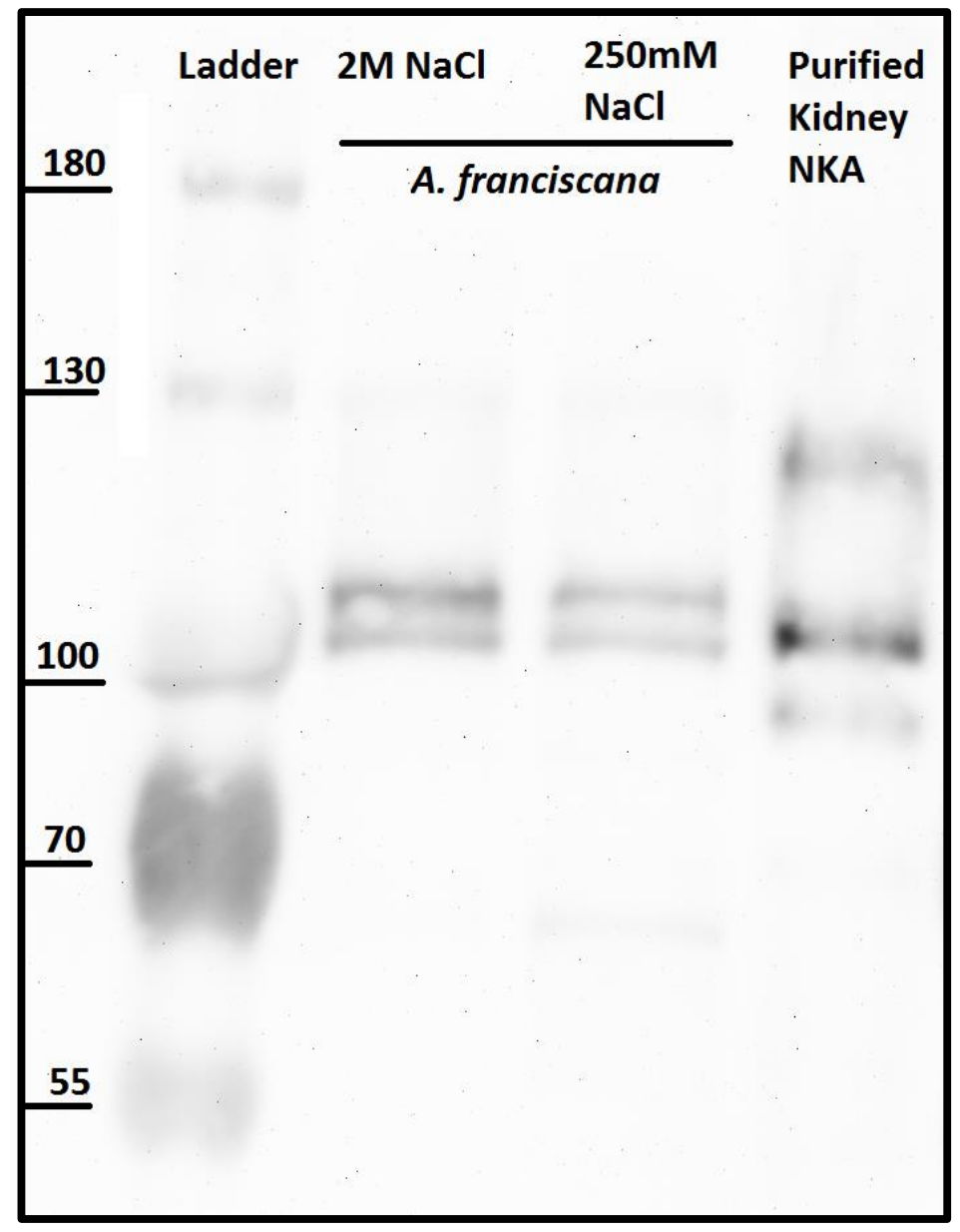

Figure 7. Western blot of NKA from brine shrimp adapted to $2 \mathrm{M}$ or $250 \mathrm{mM} \mathrm{NaCl}$. Probed with antibody for $\alpha$-subunit of NKA. Lane 1 contains a protein ladder, lane 2 contains whole-animal homogenate from $2 \mathrm{M} \mathrm{NaCl}$-adapted brine shrimp, lane 3 contains whole-animal homogenate from 250mM NaCl-adapted brine shrimp, and Lane 4, NKA control. The two bands in lanes 2 and 3 represent the two different forms of the $\alpha$-subunit, $\alpha 1(\mathrm{NN})$ and $\alpha 2(\mathrm{KK})$. 


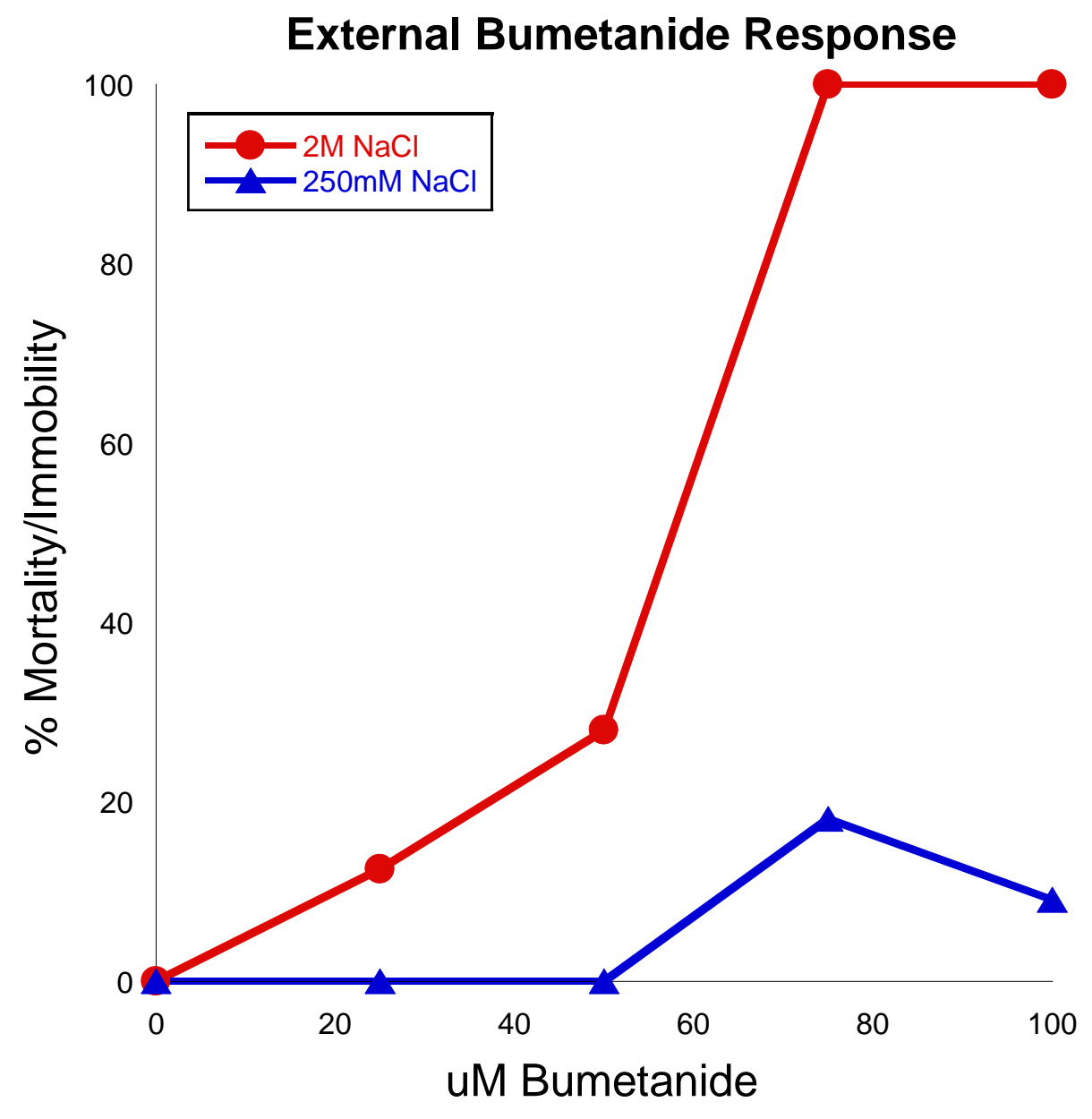

Figure 8. Dose response of bumetanide in $2 \mathrm{M}$ or $250 \mathrm{mM}$ adapted brine shrimp. Results were either response (impairment/lethality) and nonresponse. Dosing occurred over 24 hours. 


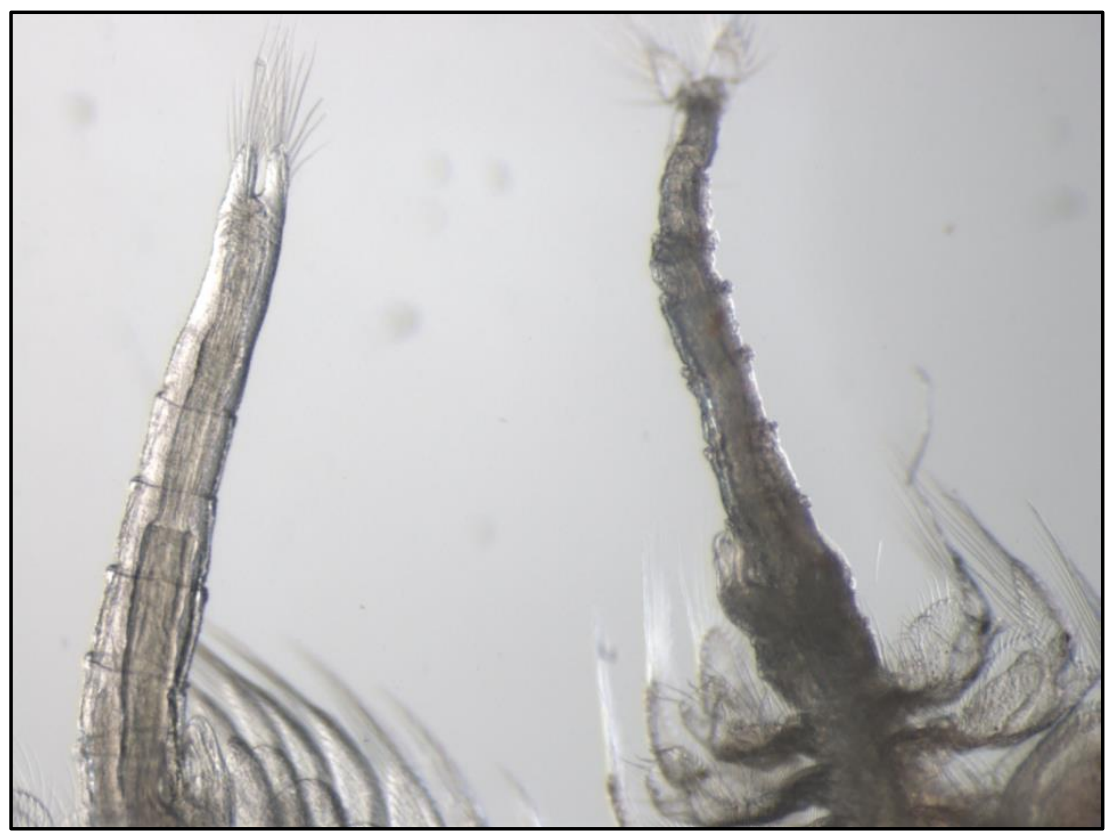

Figure 9. Comparison of water loss in brine shrimp telsons after bumetanide exposure. Left is control, right is $100 \mu \mathrm{M}$ bumetanide. 

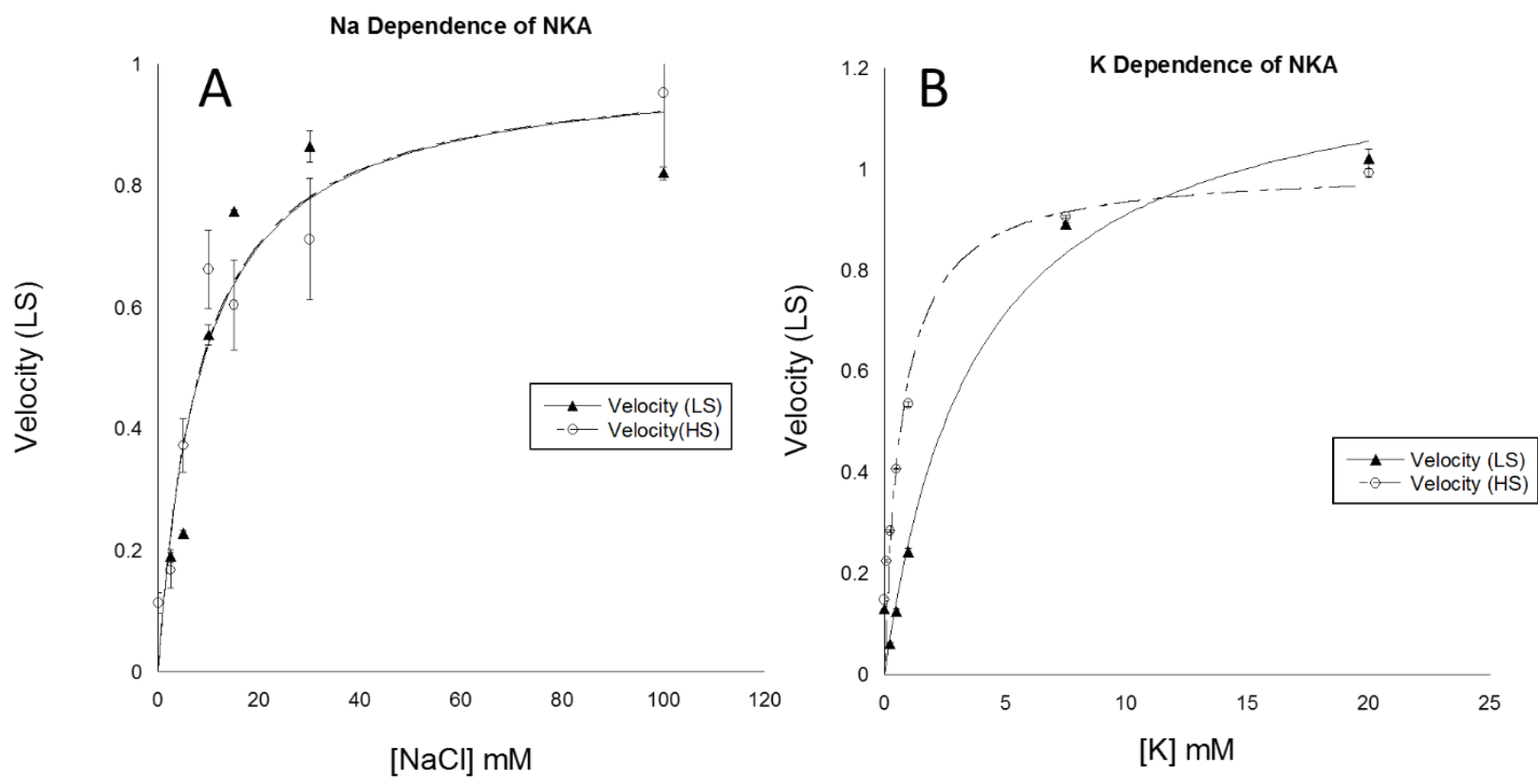

Figure 10. $\left[\mathrm{Na}^{+}\right]$and $\left[\mathrm{K}^{+}\right]$Dependence of NKA from brine shrimp. A $\mathrm{K}_{0.5}$ for $\mathrm{Na}^{+}$from $2 \mathrm{M}$ $\mathrm{NaCl}$ (high salt, $\mathrm{HS}$ ) or $250 \mathrm{mM} \mathrm{NaCl}$ (low salt, LS) adapted brine shrimp. The $\mathrm{K}_{0.5}$, from the LS group was 8.54, approximately equal to the $\mathrm{K}_{0.5}$ of the HS group (8.4). The $\mathrm{R}^{2}$ values were 0.913 and 0.933 for LS and $\mathrm{HS}$, respectively. $\mathbf{B} \mathrm{K}_{0.5}$ for $\mathrm{K}^{+}$from $2 \mathrm{M} \mathrm{NaCl}$ (high salt, $\mathrm{HS}$ ) or $250 \mathrm{mM}$ $\mathrm{NaCl}$ (low salt, LS) adapted brine shrimp. The $\mathrm{K}_{0.5}$ from the LS group was 3.78, greater than the $\mathrm{K}_{0.5}$ of the HS group (0.7). The $\mathrm{R}^{2}$ values were 0.975 and 0.946 in LS and HS, respectively. 


\section{Relative gene expression of NKA as a consequence of salt adaptation}

Quantititive PCR was performed with primers designed for the $\alpha 1(\mathrm{NN}) \mathrm{cDNA}, \alpha 2(\mathrm{KK})$, with an $\alpha$-tubulin control using two-step RT-qPCR. Amplification plots are shown in figure 11. Increasing salinity had little effect on the amplification of both the loading control $\alpha$-tubulin and the $\alpha 1(\mathrm{NN})$ (Fig 11B, 11C). However, as salinity decreased from $2 \mathrm{M}$ to $250 \mathrm{mM} \mathrm{NaCl}$, the amplification curves showed significant shifting to the right for the low-salt $(250 \mathrm{mM}) \mathrm{cDNAs}$, indicating a lower starting amount of a2(KK) mRNA in that group (Fig 11A). 


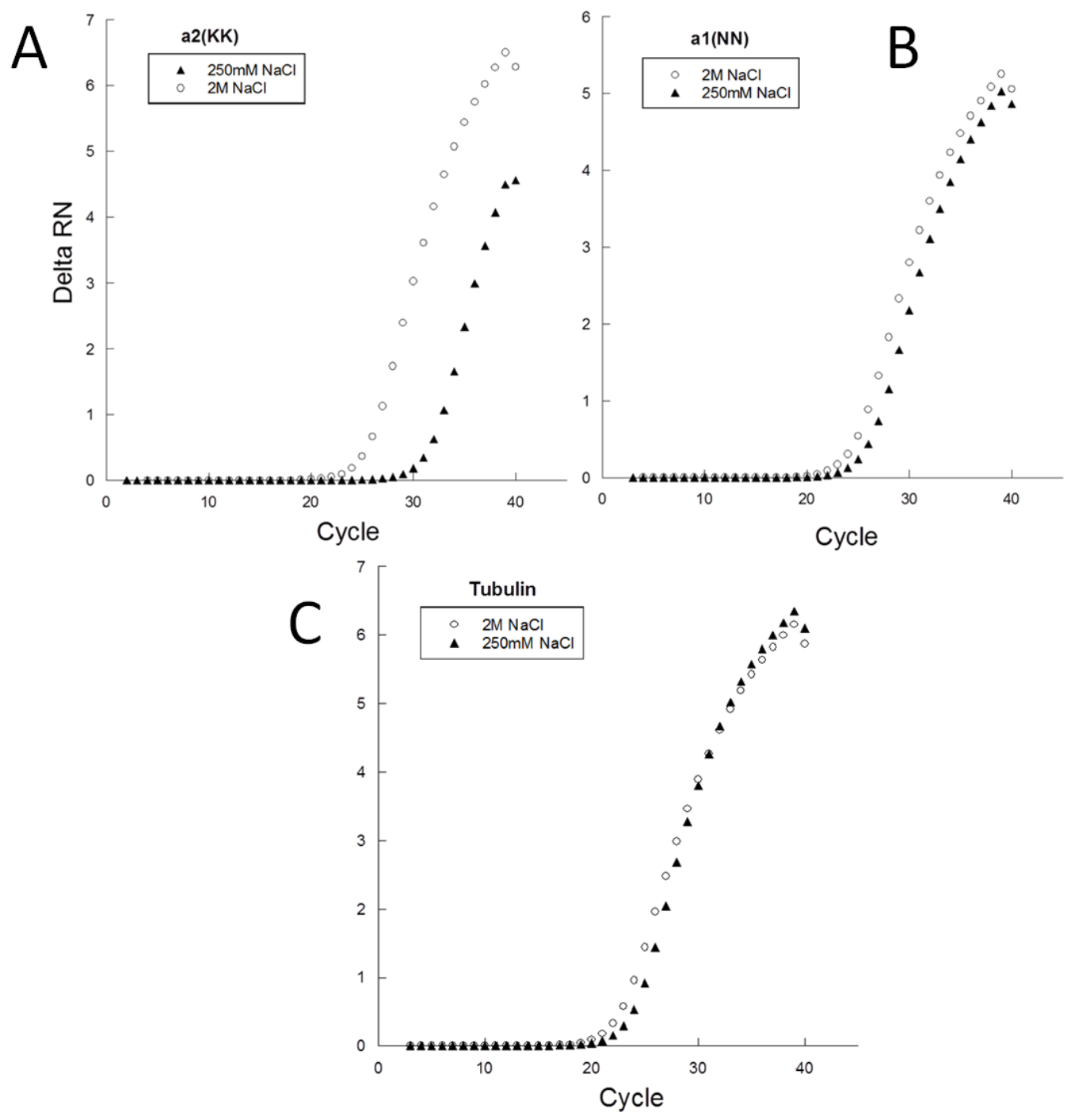

Figure 11. qPCR amplification plots of a1(NN) and a2(KK) subunits. $Y$ axis represents the change in luminescence, or delta $\mathrm{RN}$, of the reaction. The $\mathrm{x}$ axis represents the cycle number. There is no substantial shifting of the amplification plots between $2 \mathrm{M}$ and $250 \mathrm{mM}$ reared brine shrimp for the $\alpha 1(\mathrm{NN})$ or $\alpha$-tubulin transcripts, however the plot for $\alpha 2(\mathrm{KK})$ shows left shifting for the $2 \mathrm{M} \mathrm{NaCl}$ group relative to the $250 \mathrm{mM} \mathrm{NaCl}$ group. 


\section{CHAPTER IV: DISCUSSION}

Brine shrimp are crustaceans which live in inland salt lakes and are capable of adapting to extreme salinities ${ }^{11}$. They possess an altered $\mathrm{Na}, \mathrm{K}-\mathrm{ATPase} \alpha$ subunit which they upregulate in response to increased salinity ${ }^{10}$. It has been proposed that this subunit helps the brine shrimp to pump $\mathrm{Na}^{+}$across a steep concentration gradient ${ }^{10}$, however the exact stoichiometry has not been deduced until recent work from our laboratory has suggested that the $\alpha 2 \mathrm{KK}$ pumps have a unique stoichiometry of $2 \mathrm{Na}^{+}: 1: \mathrm{K}^{+}: 1 \mathrm{ATP}^{14}$. This is the first demonstration of a NKA that has a transport stoichiometry different from $3 \mathrm{Na}^{+}: 2 \mathrm{~K}^{+}: 1 \mathrm{ATP}$. In this paper, I sought to determine whether the brine shrimp a2KK pump also had a unique apical expression pattern which would directly exploit its special stoichiometry for the adaptation of brine shrimp to extreme salinities. However, a2KK is expressed in the basolateral membrane like NKA in most epithelia.

\section{Expression of the $\alpha$-subunit of the Na,K ATPase as an adaptation to salinity}

A. franciscana possess two NKA $\alpha$-subunit isoforms which share $74 \%$ identity ${ }^{10}$. The defining differences between the two $\alpha$-subunits are two asparagines, 324 and 776 in $\alpha 1(\mathrm{NN})$,

which are lysines in the second, $\alpha 2(\mathrm{KK})^{10}$. These two residues (position 324 and 776) are located in a conserved cation binding region of the NKA; they are near one of the two "shared sites". Two ion binding sites are referred to as "shared" because they reciprocally bind $\mathrm{Na}^{+}$and $\mathrm{K}^{+}$on alternate sides of the membrane. A third site, the $\mathrm{Na}^{+}$exclusive site, only binds $\mathrm{Na}^{+}$ions from the cytoplasm and deposits it extracellularly. The two lysine residues occupying locations 324 and 776 have a very distinct effect in $\alpha 2(\mathrm{KK})$, which in addition to altering ion affinities enables the enzyme to alter its stoichiometry. Its critical importance to brine shrimp salt tolerance is 
evident by its over-expression in response to increasing salinity ${ }^{10}$. Although the NKA has a wellknown canonical $3 \mathrm{Na}^{+}$for $2 \mathrm{~K}^{+}$exchange, based on Jorgensen and $A m a t{ }^{10}$ and with our laboratory have compelling data to challenge this dogma and propose that brine shrimp exploit this non-canonical mode of operation in response to extreme saline environments. Their hypothesis ${ }^{10}$ along with our findings suggest that the $\alpha 2$-(KK) subunit possesses a reduced stoichiometry ( $\left.2 \mathrm{Na}^{+}: 1 \mathrm{~K}^{+}: 1 \mathrm{ATP}\right)$ in the $\alpha 2$-(KK) compared to the well-defined canonical $\left(3 \mathrm{Na}^{+}: 2 \mathrm{~K}^{+}: 1 \mathrm{ATP}\right)$. This reduced stoichiometry is so unique (thus far the only example) that we contend it plays a critical role for the brine shrimp's remarkable ability to adapt and tolerate hypersaline conditions.

In order to determine mRNA expression differences between the high-salt-adapted and low-salt-adapted brine shrimp, quantitative PCR analysis was performed and revealed a significant upregulation of the $\alpha 2$-(KK) subunit in brine shrimp adapted to higher concentration $(2 \mathrm{M} \mathrm{NaCl})$ vs. lower concentration $(250 \mathrm{mM} \mathrm{NaCl})$, consistent with the observations of Jorgenson and Amat ${ }^{10}$. The left shift of the amplification plot for the a2(KK) subunit corresponded to an almost 2-fold increase in expression of the $2 \mathrm{M} \mathrm{NaCl}$ adapted brine shrimp group over the $250 \mathrm{mM} \mathrm{NaCl}$ adapted brine shrimp (Fig 11). This amplified expression was not seen with the ubiquitously expressed $\alpha 1(\mathrm{NN})$ subunit.

Taken together, the reduced stoichiometry of the $\alpha 2$-(KK) pump $^{10,14}$ in combination with its increased expression in response to increasing salinity, suggests an adaptive function for the $\alpha 2$ form in extreme salinities. The reduced stoichiometry may allow the brine shrimp to overcome the increased energy requirement of pumping three $\mathrm{Na}^{+}$ions against the steep concentration gradients that these organisms are able to tolerate. Thus, it stands to reason that the $\alpha 2$-(KK) isoform of the $\mathrm{Na}, \mathrm{K}-\mathrm{ATPase}$ is advantageous in adapting to high salinity. 


\section{Metepipodites are $\mathrm{Na}^{+}$and $\mathrm{Cl}^{-}$excreting organs}

Initial proposals that metepipodites may function similarly to teleost gill epithelia were based on measurements of transepithelial potential differences (TEP) and ion analyses indicating active $\mathrm{Cl}^{-}$excretion and passive $\mathrm{Na}^{+}$movement into the external media ${ }^{11}$. Additionally, morphological similarities exist between chloride cells of teleost gills and cells of the metepipodites in brine shrimp ${ }^{11}$. In teleost gill epithelia, the chloride cells are specialized for ion regulation using an extensive contiguous basal membrane providing a large surface area for the NKA to create a $\mathrm{Na}^{+}$gradient, utilized by NKCC to drive the influx of $\mathrm{Na}^{+}, \mathrm{K}^{+}$, and $2 \mathrm{Cl}^{-}$ions ${ }^{13}$. Chloride ions are then actively pumped out of the organism at the apical membrane via a CFTRchannel, which produces the measurable differences in TEP ${ }^{4}$. This effect on TEP then allows the recycled extracellular $\mathrm{Na}^{+}$to leave the organism through a single-stranded tight junction between adjacent chloride cells which are 'leaky' to cations. These ion movements allow for the maintenance of a hypotonic internal environment of the organism relative to the concentrated external environment.

I assessed these similarities in the context of different concentrations of salt-adapted brine shrimp. Membrane staining revealed a highly convoluted architecture of the metepipodite membranes with a surplus of mitochondria in relation to the surrounding phyllopodia. Both of these features resemble teleost gill chloride cells, which are mitochondrial rich and have an extensive basolateral membrane ${ }^{6}$. An abundance of mitochondria indicates a subsequent increase in available ATP, which is needed by the NKA to pump $\mathrm{Na}^{+}$across the steep concentration gradient found between the cytoplasm of the cell and the tubular lumen of the membraneous chloride cell ${ }^{13}$. It is this gradient that provides the energy for NKCC, which 
expressed in many secretory tissues for maintenance of cell volume and integrity ${ }^{21}$, to pump $\mathrm{Cl}^{-}$, along with $\mathrm{K}^{+}$and $\mathrm{Na}^{+}$, into the gill epithelial cell, where $\mathrm{Cl}^{-}$then exits down its electrochemical gradient through a CFTR-channel ${ }^{6}$.

I tested for both the presence and function of NKCC in brine shrimp with a specific inhibitor, bumetanide, in order to assess differences in functional importance between $2 \mathrm{M} \mathrm{NaCl}$ and $250 \mathrm{mM} \mathrm{NaCl}$ adapted brine shrimp. After 24 hours, little or no effect was apparent in $250 \mathrm{mM} \mathrm{NaCl}$-adapted brine shrimp, while impairment of processive swimming or death was observed in a dose-responsive manner in brine shrimp adapted to $2 \mathrm{M} \mathrm{NaCl}$ (Fig. 8). The response in $2 \mathrm{M} \mathrm{NaCl}$-adapted brine shrimp and lack of a response in $250 \mathrm{mM} \mathrm{NaCl}$-adapted brine shrimp indicates that NKCC is necessary for survival in hypersaline environments. This finding is consistent with other systems, which have observed that $\mathrm{NKCC}$ is activated upon cell shrinkage and works in sync with other membrane ion transporters to regulate cell volume through water gain and loss ${ }^{21}$. Without NKCC activity, signs of water loss were observed in the brine shrimp in concentrated media (Fig. 9).

\section{Altered ion affinity of NKA in hypersaline adapted brine shrimp}

Jorgenson and Amat identified an increase in expression of the $\alpha 2(\mathrm{KK})$ NKA subunit in $2 \mathrm{M}$ versus $250 \mathrm{mM} \mathrm{NaCl}$-adapted brine shrimp along with altered ion affinity compared to a1 $(\mathrm{NN})^{10}$. In order to determine the localization and morphological differences that may be representative of effects by $\alpha 2(\mathrm{KK})$, I measured $2 \mathrm{M} \mathrm{NaCl}$ adapted brine shrimp $\alpha 2(\mathrm{KK})$ expression in combination with altered ion affinity. The $\mathrm{K}_{0.5}$ for $\mathrm{K}^{+}$and $\mathrm{Na}^{+}$were determined by ouabain-sensitive phosphate liberation from ATP hydrolysis. My data indicate that the NKA $\left[\mathrm{K}^{+}\right]$affinity is higher in $2 \mathrm{M} \mathrm{NaCl}$ adapted brine shrimp, suggesting the $\alpha 2(\mathrm{KK})$ may have an 
altered $\mathrm{K}^{+}$affinity. An increase in $\mathrm{K}^{+}$affinity of the $\alpha 2(\mathrm{KK})$ form may be beneficial in compensating for the increased competition from $\mathrm{Na}^{+}$in a hypersaline environment. However, preliminary data from our lab demonstrates the $\alpha 2(\mathrm{KK})$ is capable of $3 \mathrm{Na}^{+} / 2 \mathrm{Na}^{+}$exchange in the absence of $\mathrm{K}^{+}$, thus the $\mathrm{K}^{+}$affinity may be skewed due to this effect ${ }^{14}$. An altered $\mathrm{K}_{0.5}$ for ion binding was observed only with $\mathrm{K}^{+}$, as the $\mathrm{K}_{0.5}$ for $\mathrm{Na}^{+}$showed no differences between groups (Fig. 10A and 10B).

\section{Proposed mechanism of salt extrusion in highly saline environments}

Due to the locations of these two lysine mutations in conserved ion-binding regions of the enzyme, it was proposed, and our lab identified, a reduced stoichiometry that may be advantageous for brine shrimp survival in extreme saline environments. This reduction in stoichiometry $\left(2 \mathrm{Na}^{+}: 1 \mathrm{~K}^{+}\right.$vs. $\left.3 \mathrm{Na}^{+}: 2 \mathrm{~K}^{+}\right)$per ATP means that there is more energy invested per ion transported, allowing the pump to remain active in $2 \mathrm{M} \mathrm{NaCl}$ environments. To date our lab is the first to report a noncanonical stoichiometry for any NKA.

The location of $\alpha 2(\mathrm{KK})$ NKA however, has yet to be identified. My first hypothesis was NKA expression may occur in the apical membrane of the gut epithelia as a mechanism for $\mathrm{Na}^{+}$ extrusion and prevention of excess $\mathrm{Na}^{+}$accumulation in the hemolymph. However, this was not the case as NKA expression was only present on the basolateral membrane of the gut epithelia in both $250 \mathrm{mM}$ and $2 \mathrm{M} \mathrm{NaCl}$ adapted animals. This illustrates that uptake of $\mathrm{Na}^{+}$ions likely occurs through the gut, into the hemolymph by the NKA. Once in the hemolymph, $\left[\mathrm{Na}^{+}\right]$and $\left[\mathrm{Cl}^{-}\right]$will rise throughout and eventually reach the metepipodites, where NKA expression remained on the basolateral membrane in both $2 \mathrm{M}$ and $250 \mathrm{mM} \mathrm{SW}$ adapted brine shrimp. However, the metepipodites did have specialized morphology similar to what exists in the chloride cells of 
teleost fishes. They possess increased mitochondrial content and membrane amplification compared to the rest of the phyllopodia, adaptations which likely help by increasing the surface area over which NKA maintain a constant concentration gradient. The brine shrimp also appear to have an increased expression of NKA in response to increased salinity in their environment, which it likely uses to create a localized steep $\mathrm{Na}^{+}$concentration gradient in the basolateral membrane, similar to teleost fish gills. The NKCC utilizes this gradient to import $\mathrm{K}^{+}$, and $2 \mathrm{Cl}^{-}$ into the cell, which may be used to extrude $\mathrm{Cl}^{-}$through a CFTR-channel at the apical membrane. The positive TEP created by exiting $\mathrm{Cl}^{-}$ions drives $\mathrm{Na}^{+}$to leave passively through leaky tight junctions between chloride cells and accessory cells ${ }^{7}$. 


\section{CHAPTER V: CONCLUSION}

The Na,K-ATPase (NKA) is an essential membrane pump that helps to establish a cell's ion gradients and membrane voltage ${ }^{1}$. It is used by many organisms to adapt to salt in their environment, such as teleost fishes, which extrude salt across their gill epithelia ${ }^{5}$. Brine shrimp (Artemia franciscana) are extreme halophiles and are known to possess an $\alpha 2$ version of the pump's catalytic $\alpha$ subunit which has 2 key asparagines to lysine substitutions $(\alpha 2(\mathrm{KK}))$ in ion binding regions ${ }^{10}$. Evidence for altered stoichiometry of this subunit as an adaptation to their extreme environments has been established ${ }^{14}$, however, the precise molecular and physiological mechanisms have not previously been clarified.

To determine how this $\alpha 2(\mathrm{KK})$ form can be utilized to tolerate extreme salinities, I performed immunohistochemical analysis on different tissues to examine localization and other adaptive characteristics. I determined the cellular localization of the NKA was expressed on the basolateral membrane, as is most common, in brine shrimp gut and metepipodites.

Gene expression was also characterized in brine shrimp adapted to 2 different salinities, and NKA ion affinity was measured from these groups as well. It appears that brine shrimp upregulate only the $\alpha 2$ form of the pump in response to increasing salinity, while the $\alpha 1$ form remains relatively unchanged. Additionally, I demonstrate the NKA apparent affinity for $\mathrm{K}^{+}$is decreased in $250 \mathrm{mM} \mathrm{NaCl}$ adapted animals, while the apparent affinity for $\mathrm{Na}^{+}$was unaltered. As $250 \mathrm{mM} \mathrm{NaCl}$ adapted animals have more of the $\alpha 1-(\mathrm{NN})$ than the $\alpha 2$-(KK) subunit compared to $2 \mathrm{M} \mathrm{NaCl}$-adpated animals based on qPCR analysis, the altered affinity can be attributed to differential ion dependencies of $\alpha 1-(\mathrm{NN})$ and $\alpha 2-(\mathrm{KK})$.

Based on these results, it was determined that brine shrimp are likely utilizing a mechanism of salt adaptation similar to that found in marine fish gills, in which salt extrusion 
occurs in a mitochondrial rich, membraneous cell layer in the metepipodites of the brine shrimp. There, basolateral NKA establishes a localized steep $\mathrm{Na}^{+}$concentration gradient, which is then utilized by another membrane transporter, $\mathrm{NKCC}$, to bring in $\mathrm{Na}^{+}, \mathrm{K}^{+}$, and $\mathrm{Cl}^{-}$in to the cell. $\mathrm{Cl}^{-}$ is actively pumped out of the apical membrane, providing a positive TEP that allows $\mathrm{Na}^{+}$to leave passively through leaky single-pass tight junctions between adjacent cells.

Brine shrimp appear to utilize a mechanism of ion regulation similar to the mechanism utilized by marine teleosts ${ }^{11}$. Their salt extruding organs, the metepipodites, appear to have many similarities with the chloride cells of teleost gills, including cells, which possess a highly amplified membrane and enriched mitochondrial content ${ }^{5}$. NKA is located basolaterally in the gut, where water and ions are taken in from the environment into the hemolymph ${ }^{9}$. NKA was also found to be expressed in the basolateral side of the metepipodites, indicating that the brine shrimp are not utilizing NKA to directly extrude $\mathrm{Na}^{+}$into the environment. In addition, brine shrimp express a more energetically favorable form of the NKA in response to salinity while the housekeeping form is not substantially upregulated during this process. My work suggests that brine shrimp are adapting to extreme salinities in their environment via the upregulation of an NKA with altered stoichiometry and regulate ions in a similar to the way that marine teleost gills function to allow for survival in extreme environments. 


\section{REFERENCES}

1. Kaplan, J.H. Biochemistry of Na,K-ATPase. Annu. Rev. Biochem. 71:511-35 (2002)

2. Geering, K. FXYD proteins: new regulators of Na-K-ATPase. Am. J. Physiol. Renal Physiol. 290 (2) F241-F250 (2006)

3. Epstein, F.H., Silva, P., Kormanik, G. Role of Na-K-ATPase in chloride cell function. Am. J. Physiol. 238(3):R246-50 (1980)

4. Degnan, K.J., Zadunaisky, J.A. Passive Sodium Movmements Across the Opercular Epithelium: The Paracellular Shunt Pathway and Ion ic Conductance. J. Membrane Biol. 55, 175-185 (1980)

5. Zadunaisky, J.A. Chloride cells in osmoregulation. Kidney Int. 49, 1563-1567 (1996)

6. Marshall, W.S. Na+, Cl-, and Zn2+ Transport by Fish Gills: Restrospective Review and Prospective Synthesis. J. Exp. Zool. 293:264-283 (2002)

7. Gonzales, R.J. The Physiology of hyper-salinity tolerance in teleost fish: a review. $J$ Comp. Physiol. B. 182:321-329 (2012)

8. Russler, D., Mangos, J. Micropuncture studies of the osmoregulation in the nauplius of Artemia salina. Am. J. Physiol. - Regul Integr Comp Physiol. 234 (5) R216-R222 (1978)

9. Croghan, P.C. The mechanism of osmotic regulation in Artemia Salina (L.): The physiology of the gut. J. Exp. Biol. 35:234-242 (1958)

10. Jorgenson, P.L., Amat, F. Regulation and Function of Lysine-substituted Na,K Pumps in Salt Adaptation of Artemia franciscana. J. Membrane biol. 221:39-49 (2008)

11. Holliday, C.W., Roye D.B., 11 R.D. Salinity-Induced Changes In Branchial $\mathrm{Na}^{+} / \mathrm{K}^{+}-$ Atpase Activity and Transepithelial Potential Difference in the Brine Shrimp Artemia Salina. J. Exp. Biol. 151, 279-296 (1990) 
12. Cozzi, R.R.F, Robertson, G.N., Spieker, M., Clause, L.N., Zaparilla, G.M.M., Garrow, K.L., Marshall, W.S. Paracellular pathway remodeling enhances sodium secretion by teleost fish in hypersaline environments. J. Exp. Biol. 218: 1259-1269 (2015)

13. Karnaky, K..J. Structure and function of the chloride cell of Fundulus heteroclitus and other teleosts. Am. Zool.,26:209-224. (1986)

14. Meyer, D.J., Eastman, J., Rui, H., Stanley, K., Roux, B., Gatto, C., Artigas, P. A Na/K pump with altered stoichiometry contributes to brine shrimp adaptation to high salinity. Biophys. J.,112:569a. (2017).

15. Paraffin Processing of Tissue. Protocols Online (2016). Available at: http://www.protocolsonline.com/histology/sample-preparation/paraffin-processing-oftissue/.

16. IHC staining protocol for paraffin, frozen and free floating sections. Abcam (2017). Available at: http://www.abcam.com/protocols/immunostaining-paraffin-frozen-freefloating-protocol.

17. Peterson, G.L., Ewing, R.D., Hootman, S.R., Conte, F.P. Large Scale Partial Purification and Molecular and Kinetic Properties of the $(\mathrm{Na}+\mathrm{K})$-activated Adenosine Triphosphatase from Artemia salina Nauplii. J. Biol. Chem. 253(13):4762-4770 (1978)

18. Bradford M.M. A rapid and sensitive method for the quantitation of microgram quantities of protein utilizing the principle of protein-dye binding. Anal. Biochem. 7;72(1-2):24854.(1976)

19. Gatto, C, Helms, J.B., Prasse, M.C., Arnett, K.L., Milanick, M.A. ATP and Pi alter access to the $\mathrm{Na}^{+}-\mathrm{K}^{+}$-ATPase transport site. Am. J. Physiol. - Cell Physiol. 289 (2) C302-C311 (2005) 
20. Haas, M., McManus, T.J. Bumetanide inhibits $\left(\mathrm{Na}^{+} \mathrm{K}^{+} 2 \mathrm{Cl}^{-}\right)$co-transport at a chloride site. Am. J. Physiol - Cell Physiol 245 (3)C235-C240 (1983)

21. Haas, M., Forbush III, B. The Na-K-Cl Cotransporter of Secretory Epithelia. Annu. Rev. Physiol. 62:515-34 (2000) 


\section{APPENDIX A: SOLUTIONS}

Sodium citrate buffer: (10mM sodium citrate, $0.05 \%$ Tween $20, \mathrm{pH} 6.0)$

Buffer HS: 25mM imidazole, 1mM EDTA, 250mM sucrose. $\mathrm{pH}=7.4$

Bradford's reagent: 100mg Coomassie blue G, 50mL ethanol, 100ml 85\% phosphoric acid.

Bring to $1 \mathrm{~L}$ with $\mathrm{ddH}_{2} \mathrm{O}$

ATPase assay Solution: 2.4mM EGTA, $96.4 \mathrm{mM} \mathrm{KCl,} 14.5 \mathrm{mM} \mathrm{MgCl}_{2}, 16 \mathrm{mM} \mathrm{Na}_{2} \mathrm{ATP}$, 239.5mM imidazole

Stopping Solution: $2 \mathrm{ml} \mathrm{H}_{2} \mathrm{O}, 2 \mathrm{ml} 1 \mathrm{M} \mathrm{HCl}, 0.13 \mathrm{~g}$ Absorbic acid, $200 \mu \mathrm{L} 10 \% \mathrm{NH}_{4} \mathrm{MoO}_{4}$ ACG Solution: 2\% Na-arsenite, $2 \%$ Na-citrate, 24mM Glacial acetic acid

TBS: 50mM Tris, $150 \mathrm{mM} \mathrm{NaCl,} \mathrm{pH} 7.6$

Blocking Solution: $10 \%$ normal goat serum, $1 \%$ BSA in TBS 